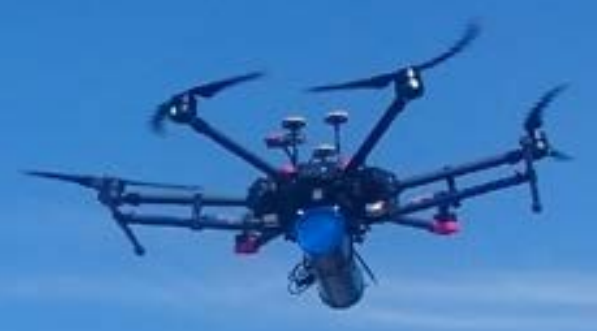

Mapping soil texture with a gamma-ray spectrometer: comparison between UAV and proximal measurements and traditional sampling

F.M. van Egmond, S. van der Veeke, M. Knotters, R.L. Koomans, D.J.J. Walvoort \& J. Limburg 

Mapping soil texture with a gamma-ray spectrometer: comparison between UAV and proximal measurements and traditional sampling 
This WOt-technical report was produced in accordance with the Quality Management System of the Statutory Research Tasks Unit for Nature \& the Environment, part of Wageningen University \& Research.

The mission of the Statutory Research Tasks Unit for Nature and the Environment (WOT Natuur \& Milieu) is to carry out statutory research tasks on issues relating to nature and the environment. These tasks are implemented in order to support the Dutch Minister of Agriculture, Nature and Food Quality, who is responsible for these issues. We provide data about agri-environment, biodiversity and soil information to compile reports as part of national and international obligations, and we work on products of the PBL Netherlands Environmental Assessment Agency, such as the Assessment of the Human Environment reports.

Cover photo: Steven van der Veeke

The 'WOt-technical reports' series presents the findings of research projects implemented for the Statutory Research Tasks Unit for Nature \& the Environment by various centres of expertise.

WOt-technical report 137 presents the findings of a research project commissioned and funded by the Dutch Ministry of Agriculture, Nature and Food Quality (LNV). 


\title{
Mapping soil texture with a gamma-ray spectrometer: comparison between UAV and proximal measurements and traditional sampling
}

\author{
Validation study
}

F.M. van Egmond ${ }^{1}$, S. van der Veeke², M. Knotters ${ }^{1}$, R.L. Koomans ${ }^{2}$, D.J.J. Walvoort ${ }^{1}$ \& J. Limburg $^{2}$

1 Wageningen Environmental Research

2 Medusa Explorations B.V. 


\section{Abstract}

Egmond, F.M. van, S. van der Veeke, M. Knotters, R.L. Koomans, D.J.J. Walvoort \& J. Limburg (2018). Mapping soil texture with a gamma-ray spectrometer: comparison between UAV and proximal measurements and traditional sampling; Validation study. Wageningen, the Statutory Research Tasks Unit for Nature $\&$ the Environment (WOT Natuur \& Milieu). WOt-technical report 137. 58 p.; 21 Figs; 7 Tabs; 19 Refs; 3 Annexes.

The need for up-to-date soil information for e.g. spatial planning, infrastructure, agriculture and nature conservation has resulted in the Dutch Key Registration of the Subsurface (BRO), which also contains the 1: 50,000 soil map of the Netherlands. Classifying properties for this map are a.o. related to soil texture. Therefore, methods are needed that efficiently and effectively measure these at the right scale level and with the required accuracy. This report describes a validation study into the possibility, accuracy and costs of mapping clay and loam content of the tillage layer $(0-30 \mathrm{~cm}$ ) by augering, by measuring gamma radiation from a UAV (unmanned aerial vehicle or drone) or on foot. The research was carried out in an agricultural area of 40 ha in the Flevoland polder, the Netherlands. The results show that the accuracy and precision of the UAV and soil-bound measurements is largely comparable. A higher point density and smaller spatial support of the ground-bound sensor have a positive effect on capturing spatial patterns, accuracy and precision. After correction for the difference in point density, results are comparable. The difference in deployment costs is limited. The effect of the use of a national reference calibration set on costs and accuracy is a lot bigger and lowers both. However, when using national calibration scale accuracy could be increased with the inclusion of more soil geographic situations. We advise assessing similar questions by first assessing the required accuracy, measurement depth and resolution, then select possible platforms and choose calibration scale within budget limits. Gamma radiation measurements for mapping soil texture is potentially a scalable and cost-efficient technique for supporting actualisation of the Soil Map of the Netherlands and for applications with higher resolution such as precision agriculture and local spatial planning.

Keywords: gamma-ray spectrometer, UAV, proximal, soil sensing, soil texture, validation, accuracy - cost

\section{Referaat}

Egmond, F.M. van, S. van der Veeke, M. Knotters, R.L. Koomans, D.J.J. Walvoort \& J. Limburg (2018). Mapping soil texture with a gamma-ray spectrometer: comparison between UAV and proximal measurements and traditional sampling; Validation study. Wageningen, the Statutory Research Tasks Unit for Nature \& the Environment (WOT Natuur \& Milieu). WOt-technical report 137. 58 p.; 21 fig.; 7 tab.; 19 refs.; 3 annexes.

De behoefte aan actuele bodeminformatie voor bijv. ruimtelijke ordening, infrastructuur, landbouw en natuurbehoud heeft geresulteerd in de Basisregistratie Ondergrond (BRO) van Nederland die onder andere de 1: 50.000 Bodemkaart van Nederland bevat. Classificerende eigenschappen hiervoor zijn onder meer gerelateerd aan de bodemtextuur. Daarom zijn methoden nodig die deze op het juiste schaalniveau en met de vereiste nauwkeurigheid efficiënt en effectief inmeten. Dit rapport beschrijft een validatiestudie naar de mogelijkheid, nauwkeurigheid en kosten voor het karteren van klei en leemgehalte van de bouwvoor $(0-30 \mathrm{~cm})$ door boringen, door metingen van gammastraling vanaf een UAV (unmanned aerial vehicle of drone) of lopend. Het onderzoek is uitgevoerd op een landbouwareaal van 40 ha in de polder van Flevoland. De resultaten laten zien dat de nauwkeurigheid en precisie van de UAV-metingen grotendeels vergelijkbaar zijn met de grondgebonden metingen. Een hogere puntdichtheid en kleinere ruimtelijke ondersteuning van de lopende meting heeft een positief effect op het verklaren van de ruimtelijke patronen, nauwkeurigheid en precisie. Wanneer voor puntdichtheid wordt gecorrigeerd, zijn de resultaten vergelijkbaar. Het verschil in kosten van de inzet van de verschillende platforms is beperkt. Het effect van het gebruik van een nationale referentie kalibratieset op de kosten en nauwkeurigheid is een stuk groter, beide worden dan lager. De nauwkeurigheid met nationale kalibratieschaal kan worden verhoogd wanneer meer bodemtypen en grondsoorten zouden zijn opgenomen. We adviseren om bij een vergelijkbare vraag eerst de vereiste nauwkeurigheid, meetdiepte en resolutie te beoordelen, vervolgens mogelijke platforms te selecteren en de kalibratieschaal te kiezen binnen budgetgrenzen. Gamma-stralingsmetingen voor het karteren van bodemtextuur vormt in potentie een schaalbare en kostenefficiënte techniek om het actualiseren van de Bodemkaart van Nederland te ondersteunen en voor toepassingen met hogere resolutie zoals precisielandbouw en lokale ruimtelijke planning.

Keywords: gammaspectrometer, UAV, proximal, bodem sensing, bodemtextuur, validatie, nauwkeurigheid - kosten

\section{(c) 2018 Wageningen Environmental Research}

PO Box 47, 6700 AA Wageningen

Phone: (0317) 480406 ;

e-mail: fenny.vanegmond@wur.nl

\section{Medusa Explorations}

PO Box 623, 9700 AP Groningen

Phone: (050) 5770280

e-mail: steven@medusa-online.com

The WOt-technical reports series is published by the Statutory Research Tasks Unit for Nature \& the Environment (WOT Natuur \& Milieu), part of Wageningen University \& Research. This document is available from the secretary's office, and can be downloaded from www.wur.nl/wotnatuurenmilieu

Statutory Research Tasks Unit for Nature \& the Environment, P.O. Box 47, NL-6700 AA Wageningen, The Netherlands Phone: +31 3174854 71; e-mail: info.wnm@wur.nl; Internet: www.wur.nl/wotnatuurenmilieu

All rights reserved. No part of this publication may be reproduced and/or republished by printing, photocopying, microfilm or any other means without the publisher's prior permission in writing. The publisher accepts no responsibility for any damage ensuing from the use of the results of this study or from the implementation of the recommendations contained in this report. 


\section{Preface}

Data acquisition techniques for soil, but also for related types of data such as vegetation, water or moisture, altitude and climate are always changing and innovating. The new techniques or improvements in hardware, software, platforms and analysis methods of existing techniques that become available are not necessarily aimed at improvements for soil data acquisition (e.g. satellite data for vegetation analysis or sensors or platforms for sensors for the mining industry) but can still be a useful addition to the toolbox and possibilities of a soil surveyor. The key is to know and assess the benefits and disadvantages, the new possibilities and limitations of these innovations in order to choose the most effective and efficient (combination of) technique(s) to answer the question at hand. For many applications this will still be the 'old-fashioned' soil auger, but for other applications 'new' soil sensing techniques can be a valuable addition. This report aims to test if recent innovations in one of these techniques, a gamma-ray spectrometer, enlarges its applicability and aims to assess what the resulting accuracies and costs are for measuring soil texture. With more knowledge of the advantages and disadvantages, the applicability of the technique for providing information about soil can be assessed, thereby potentially enlarging the soil data acquisition toolbox. 



\section{Contents}

$\begin{array}{lr}\text { Preface } & 5\end{array}$

$\begin{array}{lr}\text { Summary } & 9\end{array}$

$\begin{array}{lr}\text { Samenvatting } & 11\end{array}$

$\begin{array}{llr}1 & \text { Introduction } & 13\end{array}$

$\begin{array}{lll}1.1 & \text { Context } & 13\end{array}$

$\begin{array}{lll}1.2 & \text { Aim } & 15\end{array}$

$\begin{array}{lll}1.3 \text { Outline } & 15\end{array}$

2 Development of a lightweight gamma-ray spectrometer $\quad 17$

$\begin{array}{lll}2.1 & \text { Requirements - hardware } & 17\end{array}$

$\begin{array}{ll}2.2 \text { Elevation effect } & 18\end{array}$

2.2.1 Theory 18

2.2.2 Field measurements - elevation effect on quantity of signal 19

2.2.3 Field measurements - elevation effect on footprint of signal 19

3 Methods $r 21$

$\begin{array}{lll}3.1 & \text { Area } & 21\end{array}$

3.2 Gamma radiation measurements $\quad 22$

3.2.1 Proximal $\quad 22$

3.2.2 UAV measurements $\quad 23$

$\begin{array}{ll}3.2 .3 \text { Spectral data analysis } & 24\end{array}$

3.3 Calibration data $\quad 26$

3.3.1 Local calibration $\quad 26$

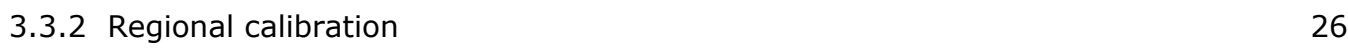

$\begin{array}{ll}3.4 & \text { Validation data } \\ \end{array}$

4 Results $\quad 29$

$\begin{array}{lll}4.1 & \text { Gamma radiation } & 29\end{array}$

4.1.1 Effect of elevation on signal strength $\quad 29$

$\begin{array}{ll}4.1 .2 \text { Effect of elevation on footprint } & 29\end{array}$

$\begin{array}{lll}4.2 & \text { Soil texture } & 32\end{array}$

$\begin{array}{lll}4.3 & \text { Cost - benefit } & 35\end{array}$

$\begin{array}{ll}4.3 .1 \text { Costs } & 35\end{array}$

4.3.2 Operational differences/benefits $\quad 36$

5 Discussion, conclusions and recommendations $\quad 37$

$\begin{array}{lll}5.1 & \text { Discussion } & 37\end{array}$

$\begin{array}{lll}5.2 & \text { Conclusions } & 39\end{array}$

$\begin{array}{lll}5.3 & \text { Recommendations } & 39\end{array}$

$\begin{array}{lr}\text { References } & 41\end{array}$

$\begin{array}{lr}\text { Justification } & 43\end{array}$

Annex $1 \quad$ Selection of sampling locations for calibration $\quad 45$

$\begin{array}{lll}\text { Annex } 2 & \text { Set up of a validation experiment } & 47\end{array}$

$\begin{array}{lll}\text { Annex } 3 & \text { Validation sampling strategy } & 53\end{array}$ 



\section{Summary}

The need for up-to-date soil information for multiple applications, such as spatial planning, infrastructure, agriculture, and nature conservation has resulted in the Dutch Key Register of the Subsurface (BRO), which contains, among other objects, the 1: 50,000 soil map of the Netherlands. Classifying properties for this map are, among others, related to soil texture. Therefore, methods are needed that efficiently and effectively measure the textural properties of the soil at the right scale level and with the required accuracy. This report describes a validation study into the possibility, accuracy and costs of mapping the clay and loam content of the tillage layer $(0-30 \mathrm{~cm})$ by augering, by measuring gamma radiation from a UAV (unmanned aerial vehicle or drone) or on foot.

A gamma-ray spectrometer is a geophysical instrument or soil sensor which is used for mapping soil texture properties with a high resolution at field or regional level. The sensor measures the concentration of radionuclides $\left({ }^{40} \mathrm{~K},{ }^{238} \mathrm{U},{ }^{232} \mathrm{Th},{ }^{137} \mathrm{Cs}\right)$ in the (top) soil $(0-30 \mathrm{~cm})$, which is a proxy of texture and origin of the parent material. However, the use of this technique depends on the accessibility of fields for the vehicles carrying the sensors. The use of soil sensors with a UAV ('drone') instead of a quad, tractor, aircraft or helicopter increases the applicability. It is more flexible, suitable for small(er) areas and can fly when crops or natural vegetation are present or when difficult driving conditions prohibit the use of a vehicle.

The research was carried out in an agricultural area of 40 ha in the polder of Flevoland, the Netherlands and is therefore located in a 60-year-old polder, with marine deposits on Pleistocene sand. The depth range of the gamma-ray spectrometer corresponds to the tillage layer $(30 \mathrm{~cm})$. In the study area this layer contains 0 to $20 \%$ clay. The measurements were performed with both a MS2000 gamma-ray spectrometer on foot and with a MS1000 gamma-ray spectrometer on a DJI M600 Pro UAV. Calibration samples were taken at 14 locations. These have been analysed in the laboratory for clay and loam content, median grain size of the sand fraction $(50-2000 \mu \mathrm{m})$, organic matter content and the concentration of radionuclides ${ }^{40} \mathrm{~K},{ }^{238} \mathrm{U},{ }^{232} \mathrm{Th},{ }^{137} \mathrm{Cs}$. Validation samples were taken at 44 locations. These locations were selected with stratified simple random sampling.

The ground-borne and UAV-borne gamma-ray spectrometer measurements are interpolated to nuclide maps and the ground-borne measurements are additionally resampled to evaluate the effect of the higher point density with respect to the UAV measurements and therefore also the effect of altitude on the gamma-ray spectrometer measurements. For the conversion of nuclide maps to soil texture maps, linear regression models were fitted to describe the linear relationship between soil properties and concentration of radio nuclides. These regression models have been fitted and applied for the locally collected calibration data and for a national reference calibration set. The differences between these maps show the effect of platform, sensor system, spatial support and calibration scale. The difference in accuracy and applicability has been assessed and the costs have been compared.

The results show that the accuracy and precision of the UAV measurements is largely comparable with the ground-borne measurements. A higher point density and smaller spatial support of the groundbound sensor have a positive effect on capturing the spatial patterns, the accuracy and precision. When the point density is corrected, the results are comparable. After correction for the difference in point density, the results are comparable. UAV is therefore a possible platform for gamma radiation measurements.

The difference in costs of the deployment of the different platforms is limited. The use of a national reference calibration set or a locally collected calibration set on costs and accuracy is a lot bigger. Both are lower when using the national set. However, the accuracy in using the national calibration scale could be increased if more soil geographic situations were included in the national calibration sets. This allows the texture of difficult-to-access or overgrown plots to be measured with a gamma-ray spectrometer. 
The applicability of the different platforms depends strongly on terrain, legislation and circumstances that are time-dependent such as weather, soil moisture and crops. We therefore advise upon assessing a demand or research question for soil texture information to first assess the required accuracy, measurement depth and resolution, then select the possible platforms and choose the calibration scale within budget limits. Gamma radiation measurements for mapping soil texture is potentially a scalable and cost-efficient technique for supporting actualisation of the soil map of the Netherlands, scale 1: 50,000, and for applications with higher resolution such as precision agriculture and local spatial planning. 


\section{Samenvatting}

De behoefte aan actuele bodeminformatie voor meerdere toepassingen, zoals ruimtelijke ordening, infrastructuur, landbouw, natuurbehoud etc. heeft geresulteerd in de Basisregistratie Ondergrond (BRO) van Nederland die onder andere de 1: 50.000 Bodemkaart van Nederland, bevat.

Classificerende eigenschappen voor deze kaart zijn onder meer gerelateerd aan de bodemtextuur en daarom zijn methoden nodig die op het juiste schaalniveau en met de vereiste nauwkeurigheid efficiënt en effectief de textuureigenschappen van de bodem in beeld brengen. Dit rapport beschrijft een validatiestudie naar de mogelijkheid, nauwkeurigheid en kosten voor het in kaart brengen van het klei en leemgehalte van de bouwvoor $(0-30 \mathrm{~cm})$ door boringen, door metingen van gammastraling vanaf een UAV (unmanned aerial vehicle of drone) of lopend.

Een gamma-ray spectrometer is een geofysisch meetinstrument of bodemsensor dat wordt gebruikt voor het karteren van bodemtextuureigenschappen met een hoge resolutie op veld- of gebiedsniveau. De sensor meet de concentratie van radionucliden $\left({ }^{40} \mathrm{~K},{ }^{238} \mathrm{U},{ }^{232} \mathrm{Th},{ }^{137} \mathrm{Cs}\right)$ in de (boven)grond $(0-30$ $\mathrm{cm}$ ), wat een benadering is voor textuur en herkomst van het moedermateriaal. Het gebruik van deze techniek is echter afhankelijk van de toegankelijkheid van velden voor de voertuigen die de sensoren dragen. Het kunnen toepassen van bodemsensoren met een UAV ('drone') in plaats van een quad, tractor, vliegtuig of helikopter vergroot de toepasbaarheid. Het is flexibeler, geschikt voor kleine(re) gebieden en kan vliegen wanneer gewassen of natuurlijke vegetatie aanwezig zijn of wanneer moeilijke rijomstandigheden het gebruik van een voertuig verbieden.

Het onderzoek is uitgevoerd op een landbouwareaal van 40 ha in de Flevopolder en bevindt zich dus in een 60 jaar oude polder, met mariene afzettingen op Pleistoceen zand. Het dieptebereik van de gamma-ray spectrometer komt overeen met de dikte van de bouwvoor $(30 \mathrm{~cm})$. In het studiegebied bevat deze laag 0 tot $20 \%$ klei. De metingen zijn verricht met zowel een MS2000 gamma-ray spectrometer te voet als met een MS1000 gamma-ray spectrometer op een DJI M600 Pro UAV. Op 14 locaties zijn kalibratiemonsters genomen. Deze zijn in het laboratorium geanalyseerd op het gehalte aan klei, slib, leem, mediane korrelgrootte van de zandfractie (50-2000 $\mu \mathrm{m})$, organische stof gehalte en de concentratie aan radionucliden ${ }^{40} \mathrm{~K},{ }^{238} \mathrm{U},{ }^{232} \mathrm{Th},{ }^{137} \mathrm{Cs}$. Op 44 locaties zijn validatie-monsters genomen. Deze locaties werden geselecteerd met een gestratificeerde, enkelvoudig aselecte steekproef.

De lopend en met een UAV uitgevoerde metingen met een gamma-ray spectrometer zijn geïnterpoleerd tot nuclide kaarten en de grondgebonden metingen zijn daarnaast geresampled om het effect van de hogere puntdichtheid van de lopende metingen ten opzichte van de UAV-metingen te kunnen evalueren en daardoor ook het effect van hoogte op de gamma-ray spectrometer metingen. Voor de omrekening van nuclide kaarten naar bodemtextuur kaarten is het lineaire verband tussen bodemvariabelen en concentratie radio nucliden beschreven met lineaire regressiemodellen. Deze regressiemodellen zijn opgesteld en toegepast voor de lokaal verzamelde kalibratiegegevens en voor een kalibratieset op nationale schaal. De verschillen tussen deze kaarten maken het effect van platform, sensorsysteem, ruimtelijke support en kalibratieschaal zichtbaar. Het verschil in nauwkeurigheid en toepasbaarheid is beoordeeld en de kosten zijn vergeleken.

De resultaten laten zien dat de nauwkeurigheid en precisie van de UAV-metingen grotendeels vergelijkbaar zijn met de grondgebonden metingen. Hierbij heeft een hogere puntdichtheid en kleinere ruimtelijke support van de grondgebonden sensor een positief effect op het verklaren van de ruimtelijke patronen, op de nauwkeurigheid en precisie. Wanneer voor het verschil in puntdichtheid tussen UAV en grondgebonden wordt gecorrigeerd, zijn de resultaten vergelijkbaar. UAV is daarom een uitvoerbaar platform voor gammastralingsmetingen. 
Het verschil in kosten van de inzet van de verschillende platforms is beperkt. Het gebruik van een nationale referentie kalibratieset of een lokaal verzamelde kalibratieset op de kosten en nauwkeurigheid is een stuk groter. Beide zijn lager bij gebruik van de nationale set. De nauwkeurigheid bij gebruik van de nationale kalibratieschaal zou echter kunnen worden verhoogd als in de nationale kalibratiesets meer bodemtypen en grondsoorten zouden zijn opgenomen. Hiermee kan ook de textuur van moeilijk toegankelijke of begroeide percelen met een gamma-ray spectrometer worden gemeten.

De toepasbaarheid van de verschillende platforms is sterk afhankelijk van terrein, wetgeving en omstandigheden die tijdsafhankelijk zijn zoals weer, bodemvocht en gewassen. We adviseren daarom om bij een vraag naar bodemtextuur informatie eerst de vereiste nauwkeurigheid, meetdiepte en resolutie te beoordelen, vervolgens de mogelijke platforms te selecteren en de kalibratieschaal te kiezen binnen budgetgrenzen. Gamma-stralingsmetingen om de bodemtextuur in kaart te brengen, vormen in potentie een schaalbare en kostenefficiënte techniek om het actualiseren van de Bodemkaart van Nederland, schaal 1: 50.000 te ondersteunen, en voor toepassingen met hogere resolutie zoals precisielandbouw en lokale ruimtelijke planning. 


\section{Introduction}

\section{$1.1 \quad$ Context}

\section{General}

The Dutch Key Register of the Subsurface (BRO) is an open data platform to provide standardised, and actual soil and geology information for the Netherlands. This enables governmental bodies and companies to make well-informed decisions on matters related to soil, geology and water. This will decrease risk costs and improve the assessment of potential in food production, nature and biodiversity, spatial planning and infrastructure and, by its open nature, lower the cost of the assessment. This also provides necessary information to achieve sustainable production and land management, thereby supporting the Sustainable Development Goals but also the Common Agricultural Policy (CAP) of the European Union, and for example the Dutch Manure \& Fertiliser Act (Meststoffenwet ${ }^{1}$ ).

The BRO includes soil profile point data and soil maps at scale $1: 50.000$. Because sedimentary and human processes alter over time the soil profile, properties and characterisation (represented by the soil types or classes), Wageningen Environmental Research is assigned by the Ministry of Agriculture, Nature and Food Quality to check the actuality of the data by validating the current maps and actualise the maps where necessary. Over the past few years the methods used for actualisation have evolved from landscape based soil classification to digital soil mapping based soil classification providing a big efficiency increase while maintaining accuracy (Kempen, 2011; Kempen et al., 2011; De Vries et al., 2014). The digital soil mapping approach is more efficient due to the use of covariates (ancillary information such as elevation and land use maps) and advanced statistical methods (geostatistics and machine learning, Knotters et al., 2017).

However, in areas with little variation in available covariates and/or less correlation between soil properties and the available covariates the required accuracy of the maps will likely demand more soil profile descriptions to be able to pinpoint the locations of soil property or soil type changes. This will be more expensive. Acquiring other, complementary covariate information to assist assessment of soil property or soil type change can then be an effective and efficient way to improve map accuracy. Possibilities for more covariates can come from satellite, aerial or ground-based remote or proximal sensing data. It is the objective of this study to test the cost effectiveness of using gamma-ray sensor information for soil texture mapping.

\section{Sensors for soil mapping}

The BRO 1 : 50.000 soil map of the Netherlands is actualised continuously. The soil type classification is determined based on observed soil properties. The classifying soil properties are often related to soil texture either in characterisation (such as \% clay) in depth (starting $x \mathrm{~cm}$ below surface) or thickness (layer is at least $x \mathrm{~cm}$ thick). When assessing possibly suitable covariates for digital soil classification mapping these should therefore be a proxy for one or more of these classifying properties. Knotters et al. (2017) provide an overview of proximal soil sensors that are suitable to measure soil hydraulic properties. These include near and mid infrared spectroscopy, gamma-ray spectrometry, electromagnetic induction methods, ground penetrating radar and other methods. Benefits of using either one of these proximal techniques or remote sensing techniques are among others high resolution, scalability, efficiency, reproducibility and supplying an extra tool in soil mapping. It should be noted that soil sensing techniques remain proxies with which the target soil properties can be estimated with a certain extent of accuracy.

\footnotetext{
${ }^{1}$ In the Bulletin of Acts, Orders and Decrees 2005 645, the Decree Implementing the Fertilisers Act has been published, with the simplified soil map as an appendix. On this map all fields in the Netherlands are classified according to the soil types of sand, loess, clay and peat. The permitted use of fertilizers depends on the soil type. Watercourses with manure-free zones are also indicated on this map. The simplified soil map is derived from the soil map of the Netherlands.
} 
When choosing a technique or combination of techniques (this includes use of available data, manual augerings, landscape analyses, remote and proximal sensing, sampling etc.) the following constraints should be taken into account:

- Can it answer the information question (soil variable of interest, parameter of interest, area, depth and period of interest)?

- Is the technique available?

- What are the practical constraints, such as trafficability?

- Can the results be aggregated or disaggregated in space and time and/ or can the technique be applied at various spatial scales?

- Are the results reproducible?

- Do the results answer the required accuracy?

- Is the technique cost effective?

In general it can be stated that the combination of open data, sensor information, calibration measurements and geostatistics/machine learning has the potential to be efficient, provided that fundamental knowledge of the soil system, geostatistics and measurement techniques is present and applied (Van Egmond \& Koomans, 2016).

A sensor type that satisfies most of these constraints for the $1: 50.000$ soil map of the Netherlands is gamma radiation (Everts et al., 2018). This technique can provide information about soil texture in the topsoil, it is available in the Netherlands, it is scalable as it can be applied on handheld, driving and aerial platforms. Under similar conditions the results are reproducible and it is expected to provide the spatial resolution required for the soil map of the Netherlands and more detailed maps that can be used for (precision) agriculture. However, this will require the use of different platforms, which is one of the reasons why we now focus on testing the use of gamma radiation for mapping soil texture using different platforms and calibration scales.

\section{Gamma radiation}

Gamma radiation as emitted by minerals in rocks and soils is a proxy for soil texture because the composition of the radiation (concentration ${ }^{40} \mathrm{~K},{ }^{238} \mathrm{U},{ }^{232} \mathrm{Th}$ ) and the amount $(\mathrm{Bq} / \mathrm{kg}$ ) is dependent on the mineral composition of the parent material (or provenance) and the size of the material (or soil texture). ${ }^{137} \mathrm{Cs}$ is present in the soil due to nuclear testing in the 1960 s and the Chernobyl accident. Measuring this passive signal with a scintillation crystal embedded in a gamma-ray spectrometer can provide a proxy for soil texture at 0-30 cm depth when calibrated using soil samples within provenance regions (Van Egmond et al., 2010). Several authors have achieved good results when predicting soil clay content of the tillage layer using gamma-ray spectrometry (Van der Klooster et al., 2011; Mahmood, 2013; Heggemann et al., 2018). Since the measurements are, compared to other sensing techniques, relatively insensitive to differences in soil moisture, they are high reproducible. For different applications, different sensor sizes and platforms are used, depending on the required accuracy, resolution and accessibility.

\section{Cost - benefit trade-off}

Two stages can be identified in the selection of an appropriate data acquisition method to provide the information that is required to answer a research question. The first is to make a selection of methods that fulfil the boundary conditions of the question and the research area. These are for instance the first four constraints mentioned above.

- Can it answer the (information) question (property and depth measured)?

- Is it available in or close to the research area?

- Can it be applied in the conditions of the research area (is the area accessible and measurable by possible platforms)?

- Can it provide information at the required resolution(s)?

After satisfying the boundary conditions, the second stage is to evaluate the cost effectiveness of the selected options or combinations of options with respect to accuracy, reproducibility, scalability, timeliness, required time and cost. This will further narrow down the possible options but will also provide requirements for the mode of application. For instance, what spatial, vertical and signal accuracy is required and how does that influence the density of measurements, the hardware 
requirements and skills of the operator or soil scientist. These specifications often have significant implications for the costs and time needed and the accuracy.

Systematic ways to balance costs and accuracy in selecting appropriate data acquisition techniques are under development and have been proposed in literature (Knotters and Vroon, 2015; Nijbroek et al., 2018). But these trade-off methods need input about the costs and resulting accuracies of data acquisition techniques. It is our aim to provide such information for regular soil sampling and a sensor technique that can be suitable to gather information for BRO in this study.

\subsection{Aim}

The objective of this study is to assess the possibility, accuracy and costs associated with different measurement strategies (platform, sensor size, calibration scale) for measuring soil texture in the topsoil $(0-30 \mathrm{~cm})$. This can be subdivided in the following research questions:

1. Is it possible to mount a gamma-ray spectrometer under a UAV to survey soil texture?

2. What is the quality of the UAV borne data compared to a ground-borne survey and normal soil sampling $(0-30 \mathrm{~cm})$ :

a. In spatial resolution?

b. In accuracy of the predicted clay content?

3. How do survey costs compare between different measurement strategies (platform, sensor size, calibration scale) for measuring soil texture in the topsoil $(0-30 \mathrm{~cm})$ ?

4. What is the practical advantage of a UAV survey compared to other methods?

5. What would be an adequate strategy to choose platform, sensor, survey specifications and analysis for $0-30 \mathrm{~cm}$ soil texture mapping?

\subsection{Outline}

This report will aim to address the aim and research questions as outlined in 1.2. The context of the aim and the choice of sensor is described in Chapter 1. Chapter 2 will address research question number 1 . The methods used to investigate the answers to research questions 2 to 4 are described in Chapter 3. The results of this study are reported in Chapter 4. These results are discussed in Section 5.1, which lead to the conclusions and recommendations as listed in Section 5.2 and Section 5.3. 



\section{Development of a lightweight gamma-ray spectrometer}

The challenge of acquiring data at the required accuracy and for a reasonable cost and in most field circumstances has prompted Medusa Explorations, a geophysical sensor and service company in Groningen, the Netherlands, to develop a lightweight gamma-ray spectrometer that can be used on a UAV. It is expected this will allow measurements in less accessible terrain, provide higher resolution than aerial measurements (airplane) and is cheaper than ground-based measurements because, for example, obstacles like field fences and ditches are not a problem. Before this could be tested in a validation study, the lightweight gamma-ray spectrometer needed to be developed first. As an additional consequence of measuring at low altitude, new calibration models had to be developed for the data analysis.

\subsection{Requirements - hardware}

Each UAV has a specific maximum payload (weight it can carry) and therefore limits the weight and size of the sensor that can be attached. Gamma-ray spectrometers are typically heavy due to the weight of the scintillation crystal. The size and weight of the sensor are reversely correlated with the spectral signal resolution. The bigger the crystal, the higher the accuracy, the bigger the weight, the higher the price. In UAV's roughly the same holds true, the bigger the UAV, the higher the payload, the higher the price. This means that accuracy of the signal and size and weight/payload need to be balanced.

The requirement set in this study is that the sensor needs to fit underneath a DJI M600 Pro UAV with a payload of $6 \mathrm{~kg}$ (see Figure 1). The UAV has RTK-GPS for flight navigation. This requires the gammaray spectrometer to:

- Decrease in size

- Decrease in weight until max $6 \mathrm{~kg}$

- Needs to be low in energy consumption (as batteries are very heavy)

- Needs to be autonomous in GPS and data logging.

To this end, Medusa developed the MS1000 spectrometer with a 1 litre NaI scintillation crystal.

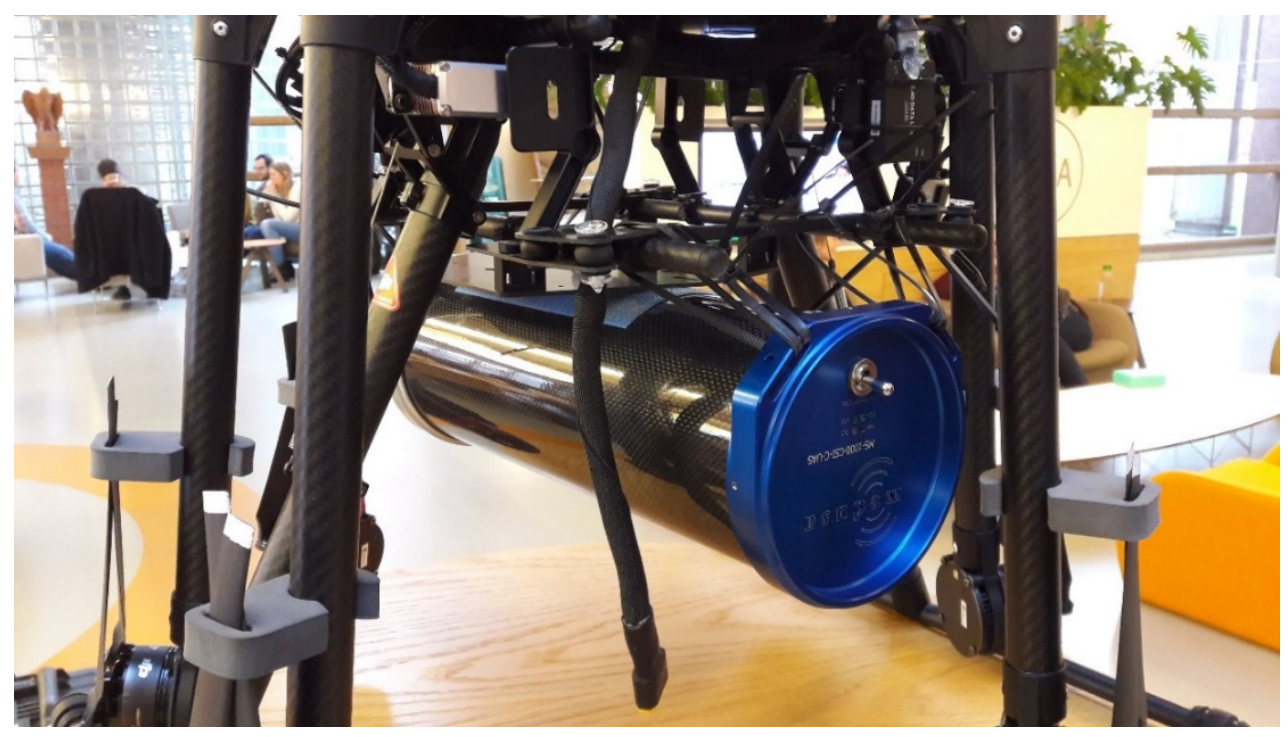

Figure 1: MS1000 gamma-ray spectrometer underneath a UAV 


\subsection{Elevation effect}

\subsubsection{Theory}

The signal as measured with the gamma-ray spectrometer is a radiation spectrum. To derive the concentrations of ${ }^{40} \mathrm{~K},{ }^{238} \mathrm{U},{ }^{232} \mathrm{Th}$ from that spectrum it is analysed with Full Spectrum Analysis (Hendriks et al., 2001) that uses standard spectra of these nuclides (representing the spectrum of 1 $\mathrm{Bq} / \mathrm{kg}$ of that nuclide) to calculate the concentration in a Chi-squared approach (Figure 2).
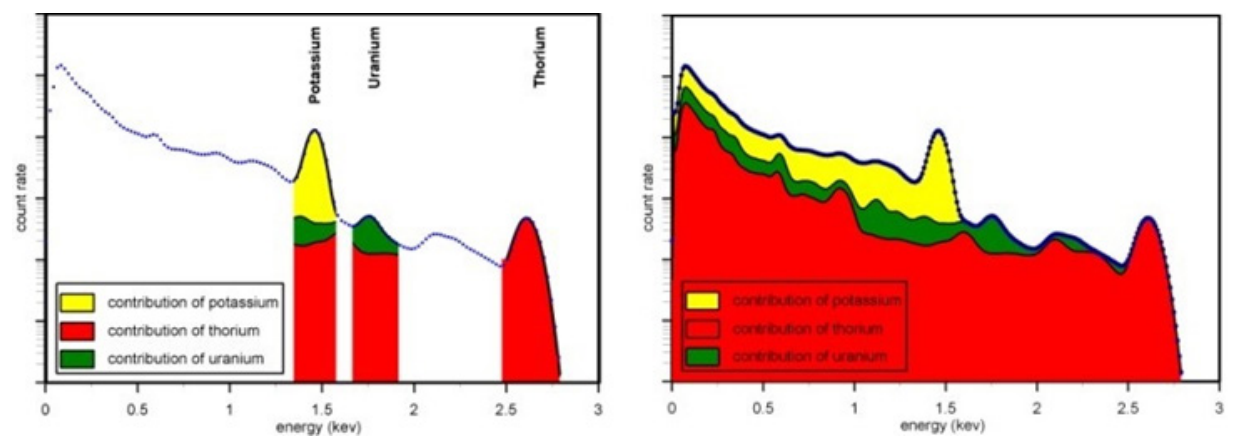

Figure 2: Left: Classic 'Windows' analysis to determine the concentration of nuclides in a spectrum. Right: 'Full Spectrum Analysis' to determine the concentration of nuclides in a spectrum.

These standard spectra are dependent on the sensor and on the geometry in which it is used. The sensors are therefore 'calibrated' in a known setup (Van der Graaf et al., 2011) and the geometry of measurement is simulated by Monte Carlo simulations.

UAV based measurements have a geometry that differs from ground-based measurements and this effect needs to be accounted for in data analysis. We expect effects on the quantity of the signal that reaches the sensor and we expect that the footprint (the area that contributes to the signal) is increased (Figure 3).

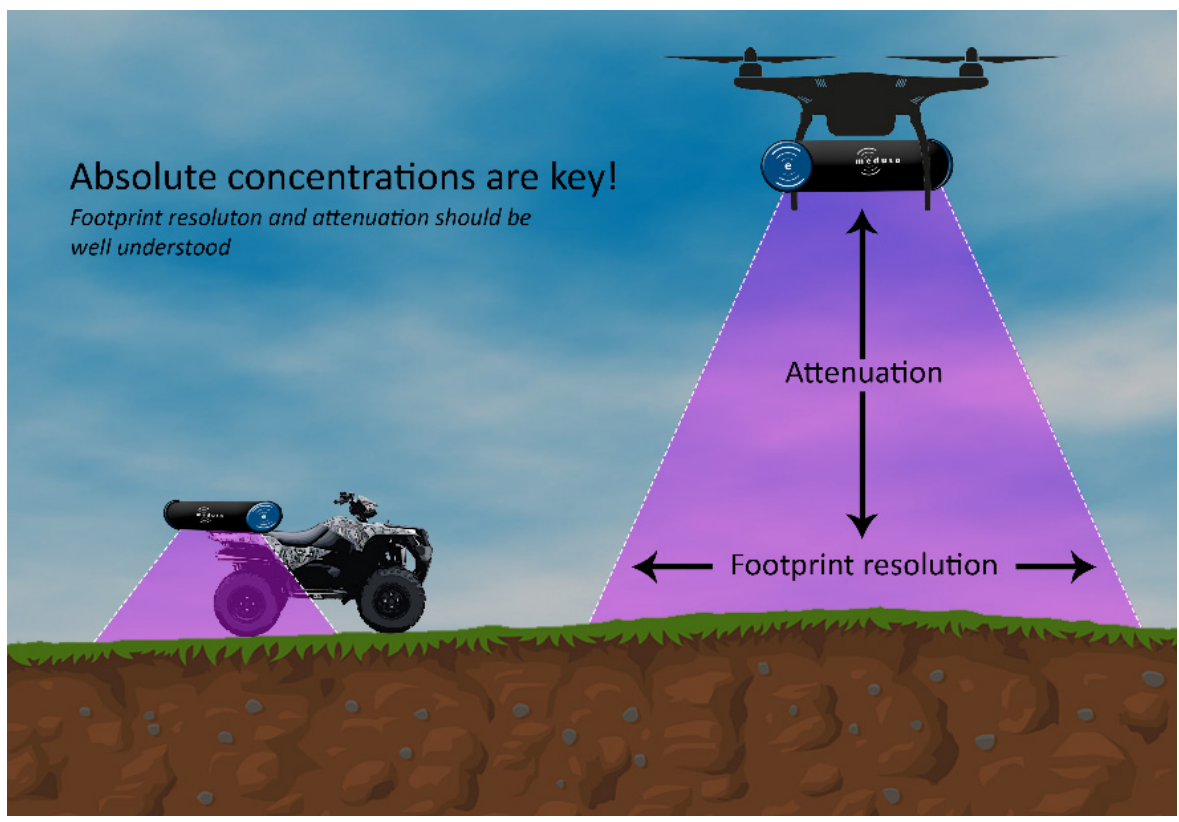

Figure 3: Schematic illustration of effect of elevation.

The exact result of these effects is difficult to determine analytically because they cause a complex change in the shape of the spectra. Therefore Monte Carlo simulations are used. The current calibration procedure to calibrate the ground-based gamma-ray spectrometers has been carefully designed to compensate for this effect for a specific height of $80 \mathrm{~cm}$. The expectation is that it will be easier to discern details at short distances in ground-based measurements. 


\subsubsection{Field measurements - elevation effect on quantity of signal}

Gamma radiation is emitted uniformly in all directions by radioactive nuclides in the ground. The radiation is absorbed by matter whereby the probability that it is absorbed is proportional to the mass of the material through which it moves. An air-bound measurement has a thicker layer of air between the (radiation emitting) ground and the sensor, in comparison with a soil-bound measurement. This increases the chance of radiation being absorbed which means less radiation will reach the detector.

\subsubsection{Field measurements - elevation effect on footprint of signal}

Apart from the effect of the thickness of the layer of air in between the source and sensor, also the 'table lamp effect' needs to be taken into account. The detector cannot distinguish in which direction the radiation enters. Because radiation is emitted in all directions, the gamma-ray spectrometer measures radiation from a larger volume when the detector is placed higher above the ground. This is shown diagrammatically in Figure 3 where the size of this surface, also called the footprint, can be approximated with a projection in the form of a table lamp, hence the name 'table lamp effect'.

Figure 4 depicts a schematic representation of the relative contribution of various sections in the ground to the total signal when the gamma-ray spectrometer is placed at an elevation of 40 meters above the ground.
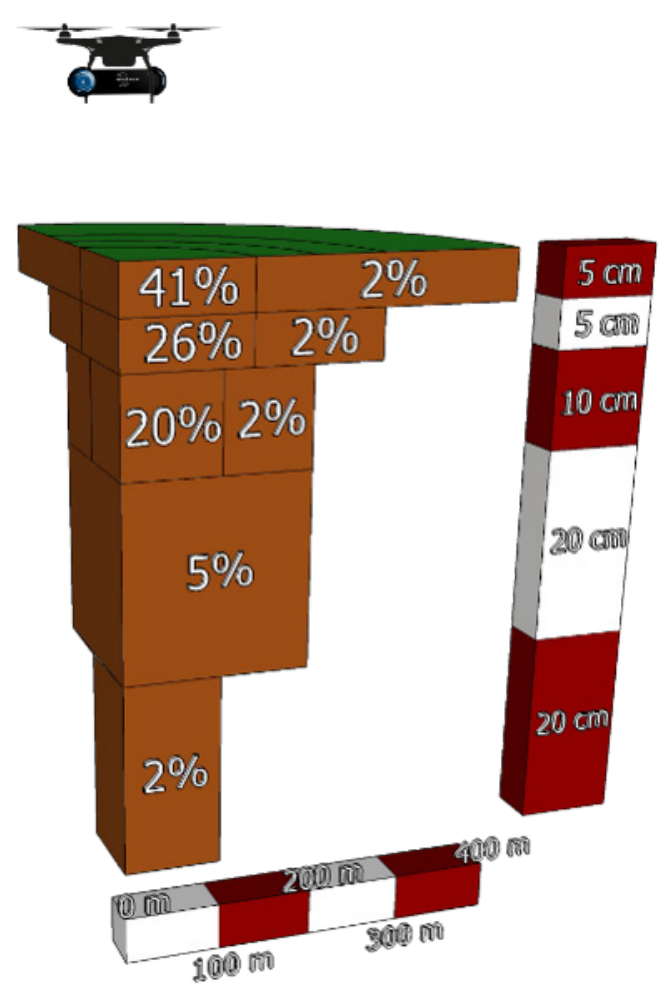

Figure 4: Schematic model of origin of contribution to signal. Values have been obtained by using Monte-Carlo simulation software (MCNPX). Note that the horizontal scale is in meters and the vertical scale is in centimeters. 



\section{Methods}

\section{$3.1 \quad$ Area}

The research area is a 40 hectare area consisting of several fields in the South East corner of the Flevoland polder, just east of Dronten, the Netherlands (Figure 5). The polder is about 60 years old. The area was selected to maximise the differences in soil types (Figure 6), resulting in a clay content range between 8 and 20\%. The maximum elevation difference is 1.4 meter (Figure 7 ). The procedure to select the area is described in Knotters et al. (2017) in Appendix 1. This Appendix is added to this report as Annex 2 since it directly describes the selection of the study area in this study and the selection of sampling locations for calibration and validation (Annex 1 and 3). The boundary conditions to select this area were:

- The study area should be in the East of Flevoland due to efficiency with other ongoing work for BRO.

- The area should be contiguous.

- The area should have a wide range of (physical) soil properties.

Boundary conditions that resulted from Dutch legislation with respect to UAV's are:

- No built up area.

- At least $10 \mathrm{~km}$ form an airport.

- At least $50 \mathrm{~m}$ from $80 \mathrm{~km}$ roads.

- At least $150 \mathrm{~m}$ from highways.

- At least $150 \mathrm{~m}$ from high voltage pylons and high voltage lines.

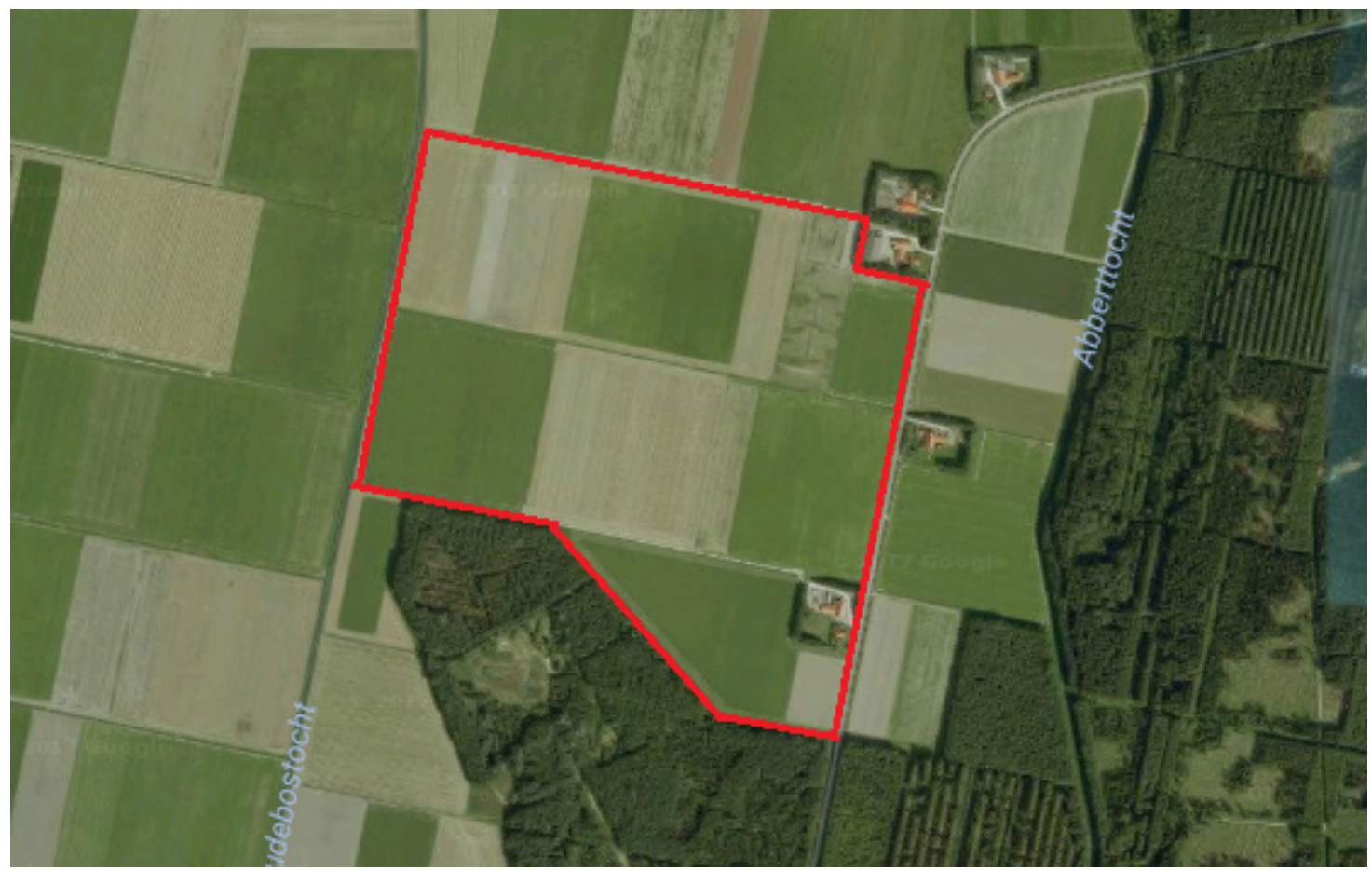

Figure 5: Aerial picture of study area, indicated by a red line. 


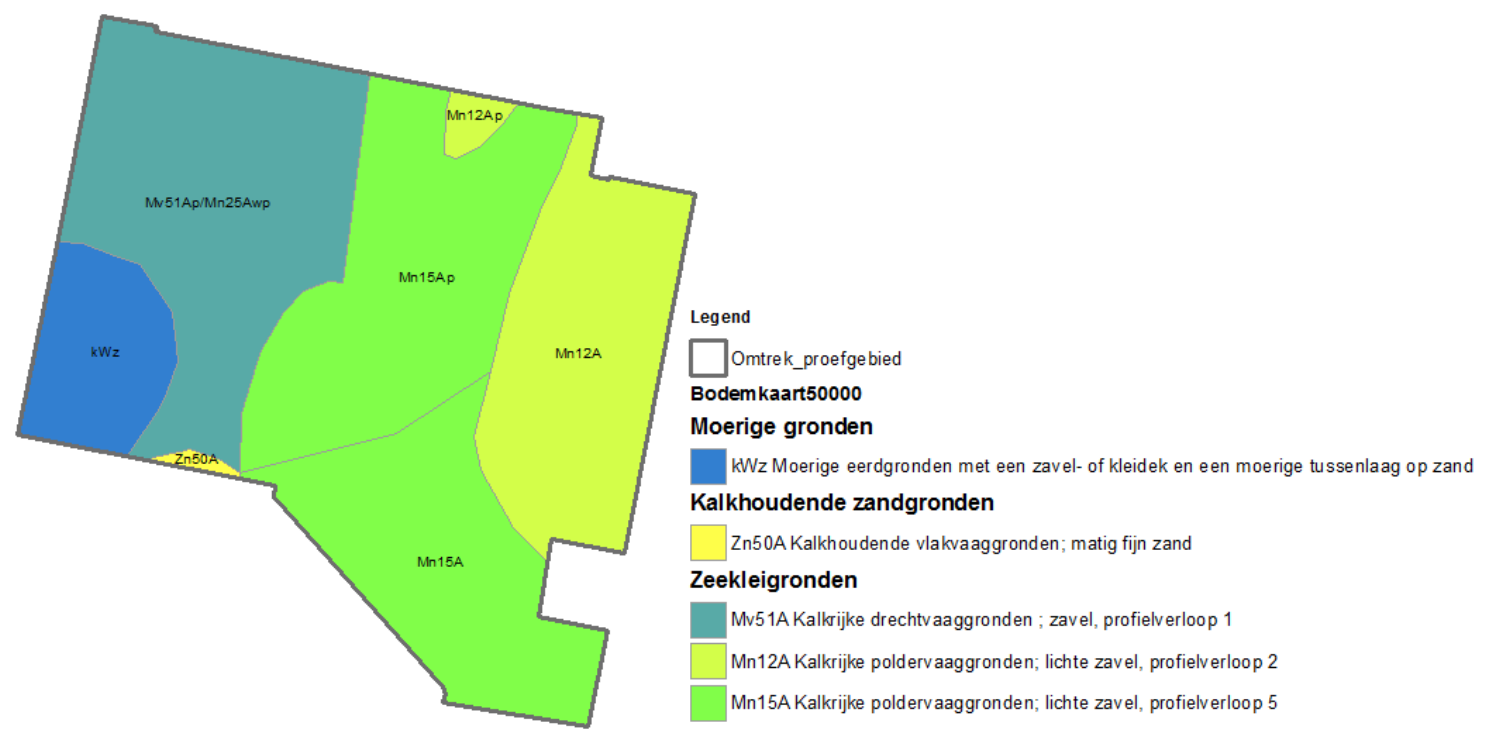

Figure 6: Soil map of the research area with Dutch soil classification classes
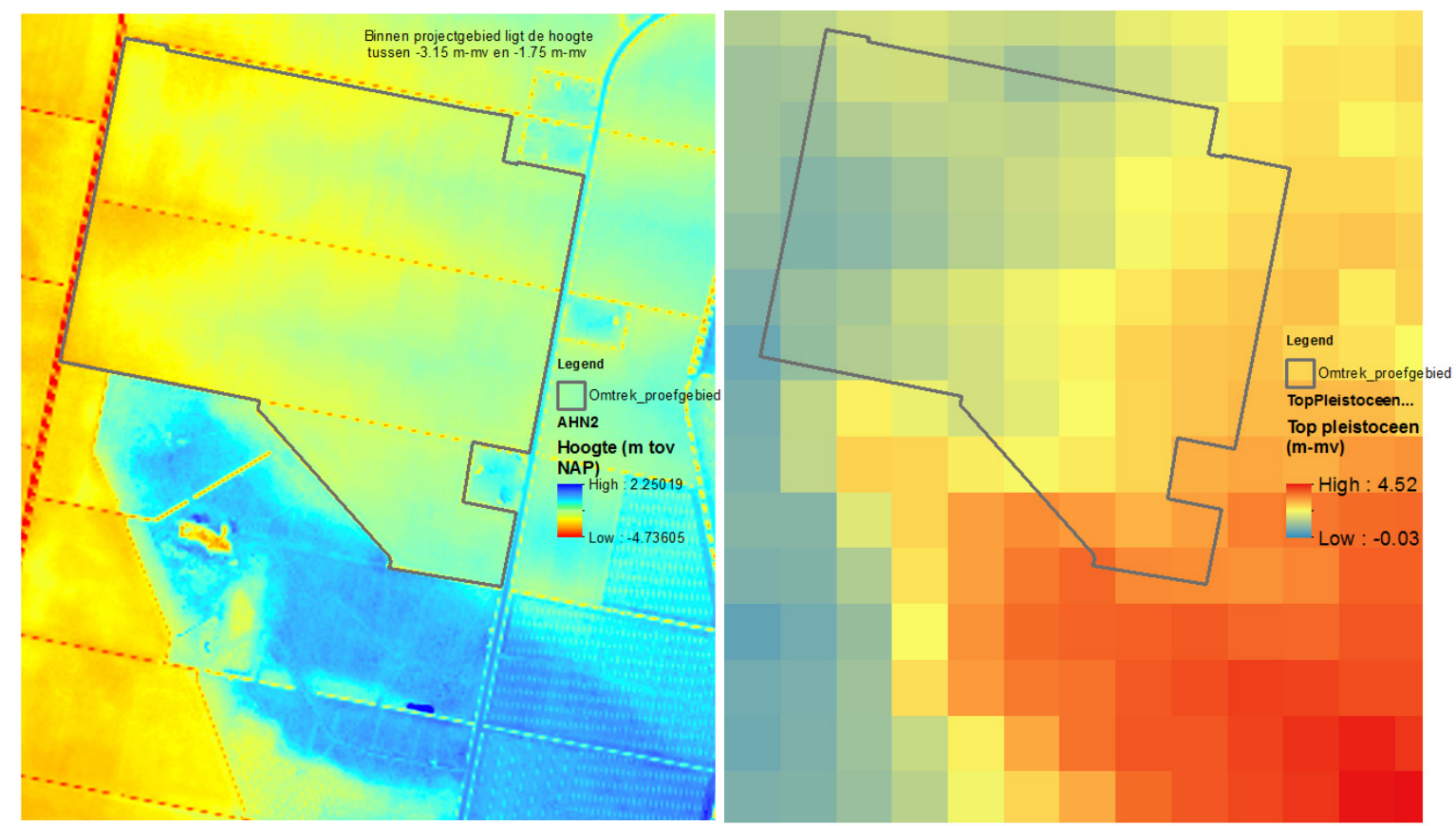

Figure 7: Left: altitude map of the study area (-4 to $2.2 \mathrm{~m}$ below/above sea level). Right: depth of Pleistocene sands (0.03- - $4.5 \mathrm{~m}$ to surface)

\subsection{Gamma radiation measurements}

\subsubsection{Proximal}

The ground-based gamma-radiation measurements were performed on foot by a surveyor carrying a 2 litre CSI gamma-ray spectrometer (Medusa MS2000) and GPS (DGPS/WAAS/EGNOS), attached to a backpack. The spectrometer was elevated from the ground at a standard distance of $80 \mathrm{~cm}$. The sensor logs one spectrum every second $(1 \mathrm{~Hz})$. The average walking speed is $5 \mathrm{~km} / \mathrm{hr}$. The entire area is measured along predetermined longitudinal lines. These lines run from north to south, with a line spacing of 24 meters (Figure 9). The measurements were performed on 16 March 2017. Locally some wet spots were present on the fields but the majority was fairly dry (Figure 8). Crops had not surfaced yet. The weather was quiet and sunny. The measurements took about 8 hours. 


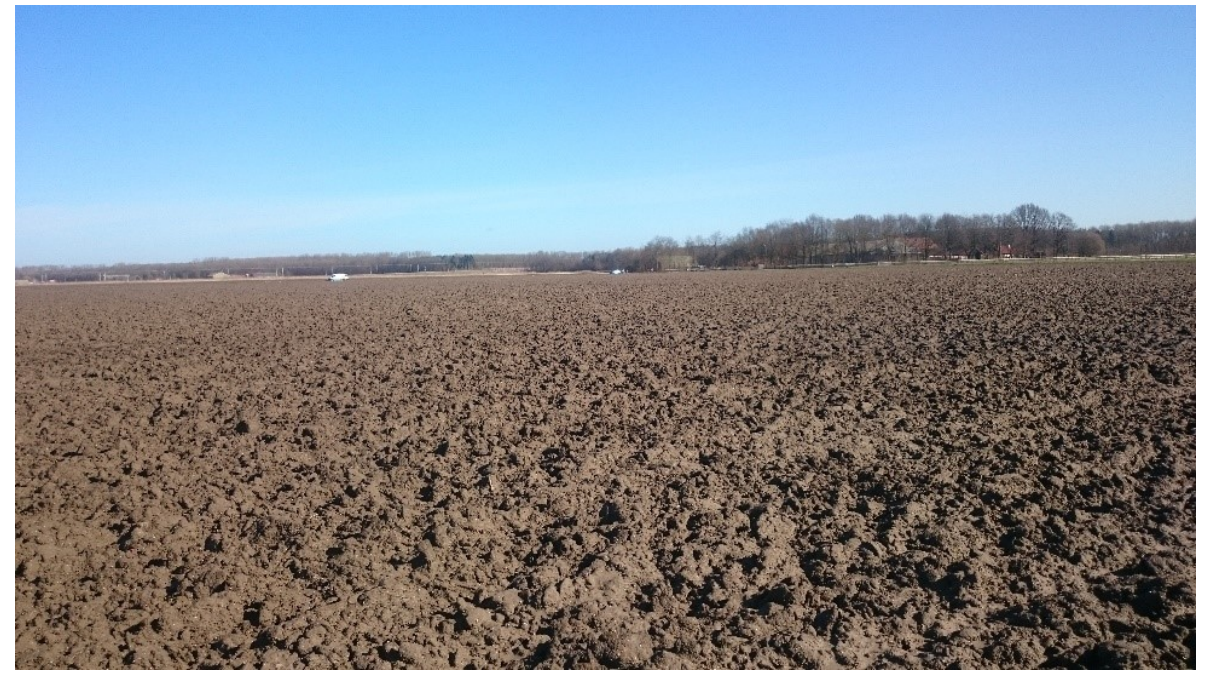

Figure 8: Field conditions during ground-based measurements (16 March 2017)

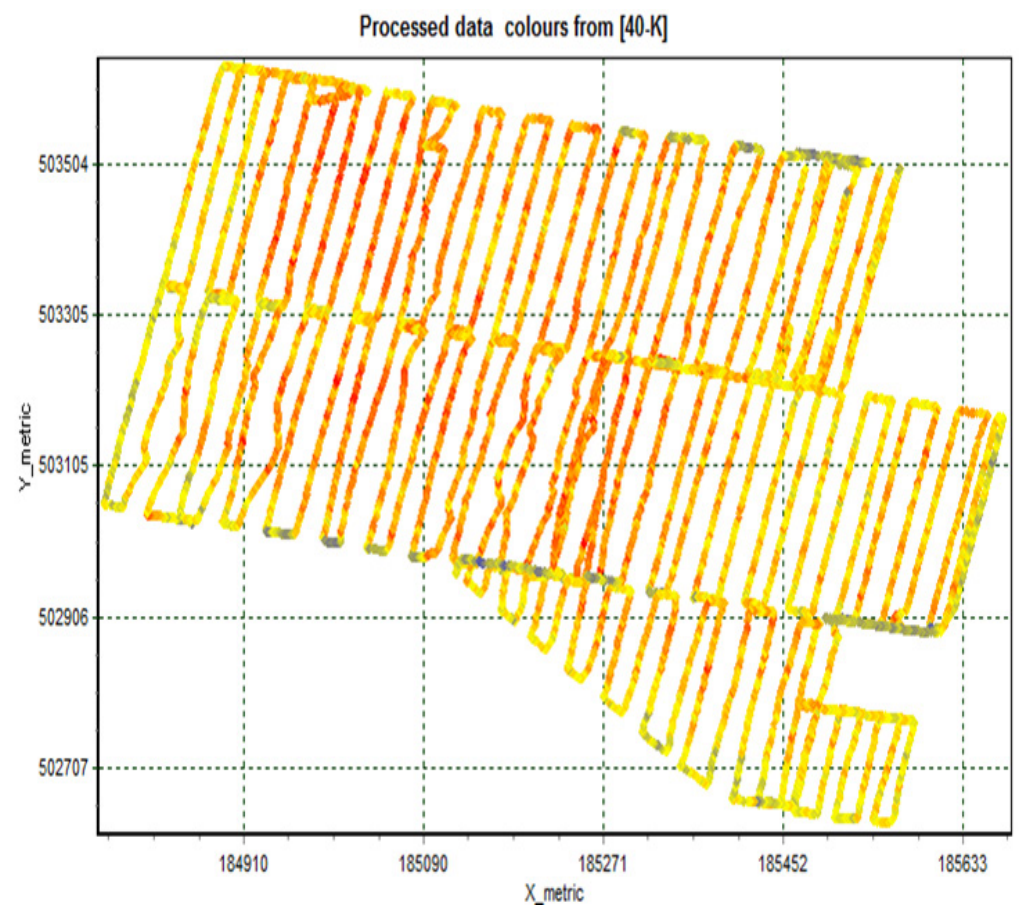

Figure 9: Measurement density in ground-based measurements. The $X$ and $Y$ scales of this map are not comparable, the map is therefore compressed.

\subsubsection{UAV measurements}

After two failed attempts at 10 and 16 March 2017 due to hardware problems, a third measurement with a larger and more powerful UAV was carried out on 30 May 2017 (Figure 10). Meanwhile the crops had surfaced on the fields; potatoes, onions, beets, carrots and grass. The DJI M600 Pro UAV was supplied by vliegend.nl and equipped with a GPS RTK system for flight operation. This UAV is specified to fly with a maximum of $6 \mathrm{~kg}$, making it possible to fly with the Medusa MS1000 sensor that contained a 1 litre NaI scintillation crystal and has a GPS (DGPS/WAAS/EGNOS). It logs a spectrum every second $(1 \mathrm{~Hz})$. It was a sunny day with little wind so there were no restrictions for flying. Due to an update of the UAV software the pre-programmed lines were lost. Therefore, the measuring lines had to be drawn on site and did not match the measurement lines of the ground-based measurement. Line spacing was 36 meter.

There were three battery sets available for the UAV and on each battery the UAV could fly for 10-15 minutes. These batteries had to cool for half an hour and then recharge for one and a half hours. The limiting factor of the day were the batteries versus time. The measurement was started at 11 o'clock 
in the morning and cancelled at 5 o'clock at the request of the UAV pilot. Approximately $2 / 3$ of the intended study area was measured with a UAV at 15 meters elevation. Average measurement speed is $11 \mathrm{~km} / \mathrm{hr}$ (see Figure 11).

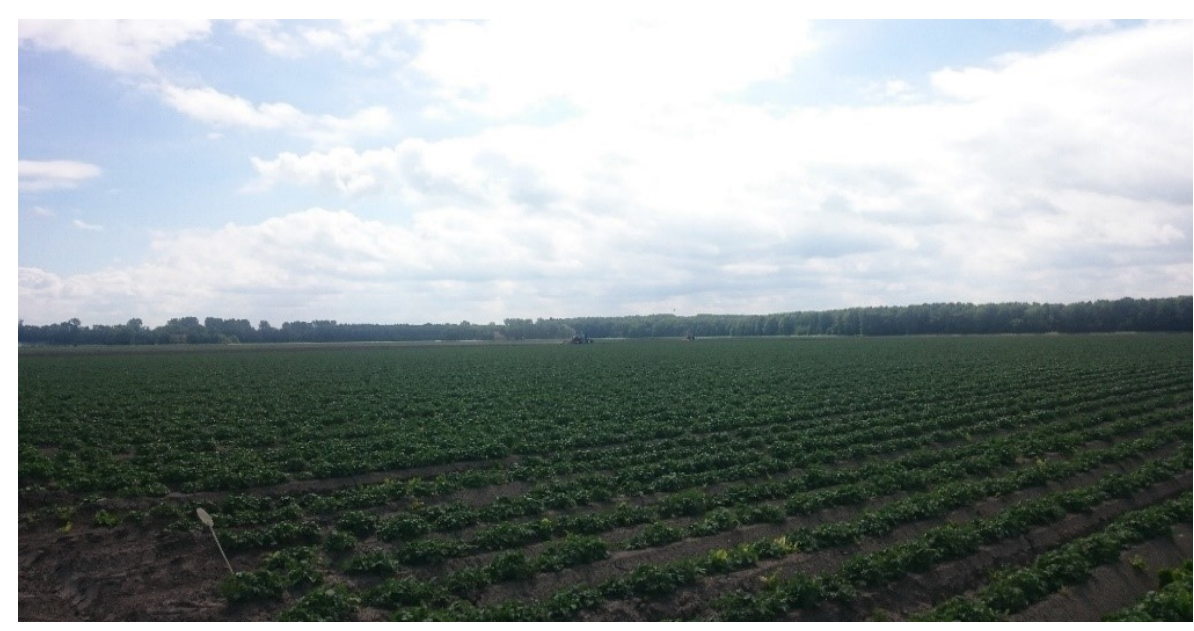

Figure 10: Field conditions during UAV based measurements (30 May 2017)

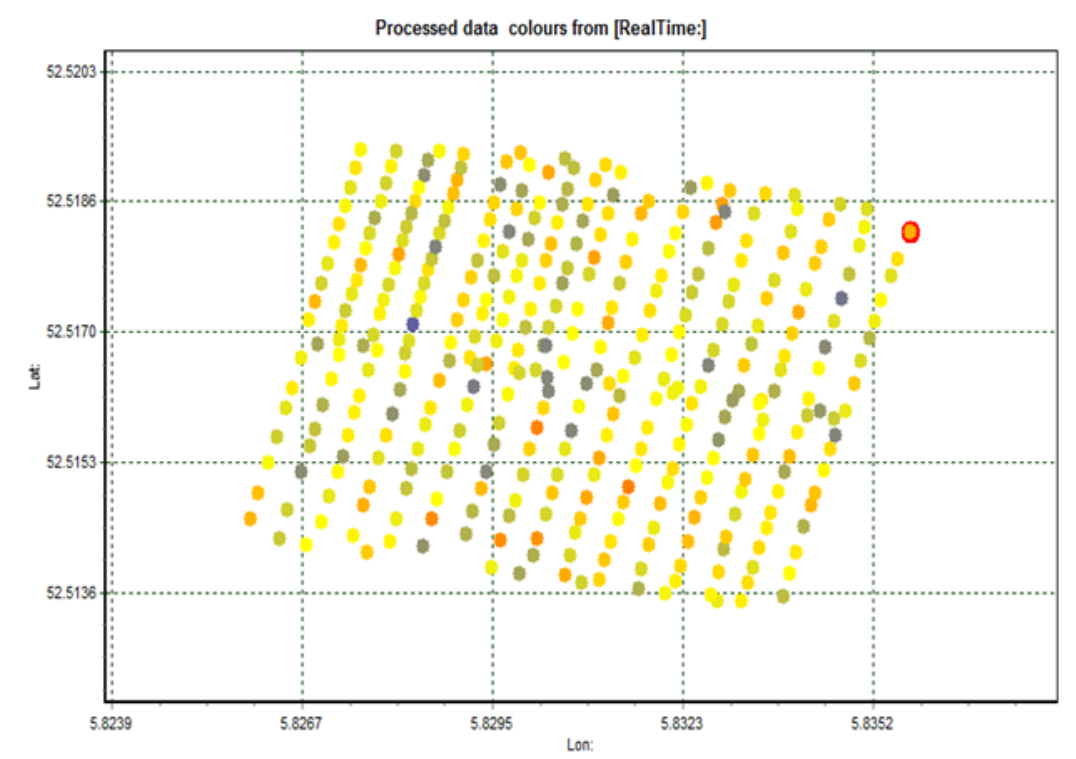

Figure 11: Measurement density in UAV based measurements

\subsubsection{Spectral data analysis}

The dataset of the ground-based measurements consists of many more data points than the UAV based measurements (Figure 7 and Figure 9) as a result of differences in line spacing and measurement speed. To ensure that differences in dataset size, detector type and measuring speed have the smallest possible effect on the analysis of accuracy differences as a result of measurement height, the data sets have been made as similar as possible. For this:

- The measurement uncertainty per measuring point has been made equal by using various repeated averages in GAMMAN (spectral analysis software developed by Medusa Explorations).

- In GIS the nearest ground-based measurement point was matched to each UAV based measurement point using a spatial join. This means that both datasets have exactly the same number of points (from the ground-based measurements the actually measured $x, y$ values were used in the further analysis). The difference in information density is depicted in Figure 12, Figure 13 en Figure 14.

- A semivariogram has been estimated and modelled for each dataset. The nugget being composed of the measurement error per point and the short distance variation.

- The datasets were interpolated using point Kriging (with the software package Golden Software Surfer 12). 
Both sensors were analysed with a calibration file that was suited for each detector in each geometry. The UAV based measurements were analysed using the GSF file (which are GAMMAN calibration files, these files are named here for reasons of reproducibility) S1AA0120_90x160NaI_15-05-

17_KUThCs.a2320 (flatbed) and with a repeated average of 10 seconds. The ground-based measurements were analysed using the GSF file 90x310csI_15-03-2017_kuthcs.a2320 (flatbed) with a repeated average of 4 seconds. The different settings of repeated average were chosen such that statistical uncertainties of the datapoints are identical. A "normal" Full Spectrum Analysis (Section 2.2) (Hendriks et al., 2001) was used for both analyses.

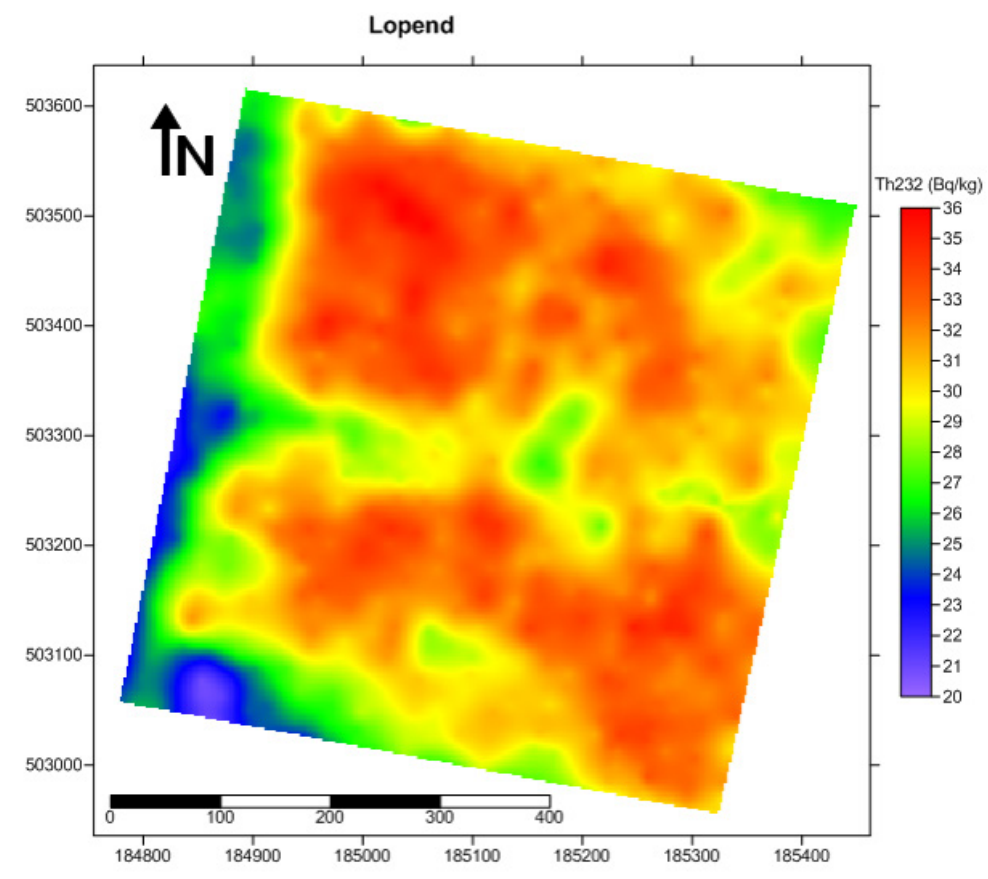

Figure 12: Interpolated ${ }^{232}$ Th map of ground-based measurements at original point density clipped to the UAV measured area.

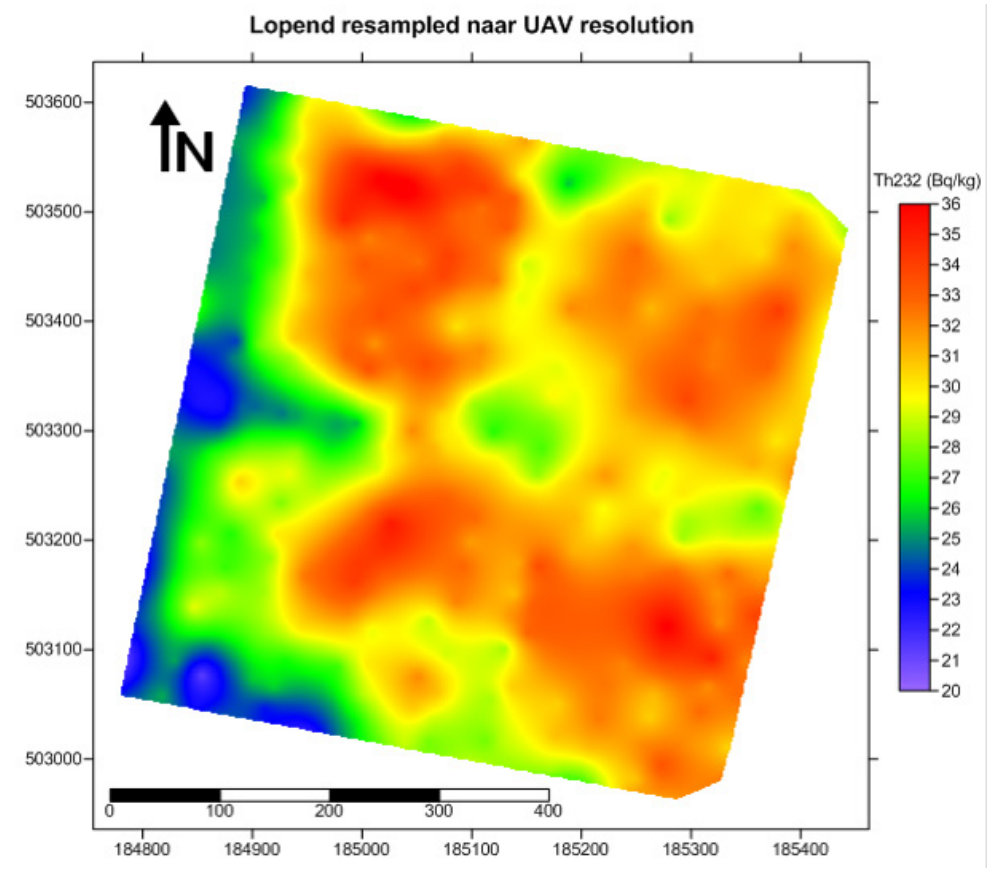

Figure 13: Interpolated ${ }^{232}$ Th map of ground-based measurements resampled to UAV point density. 


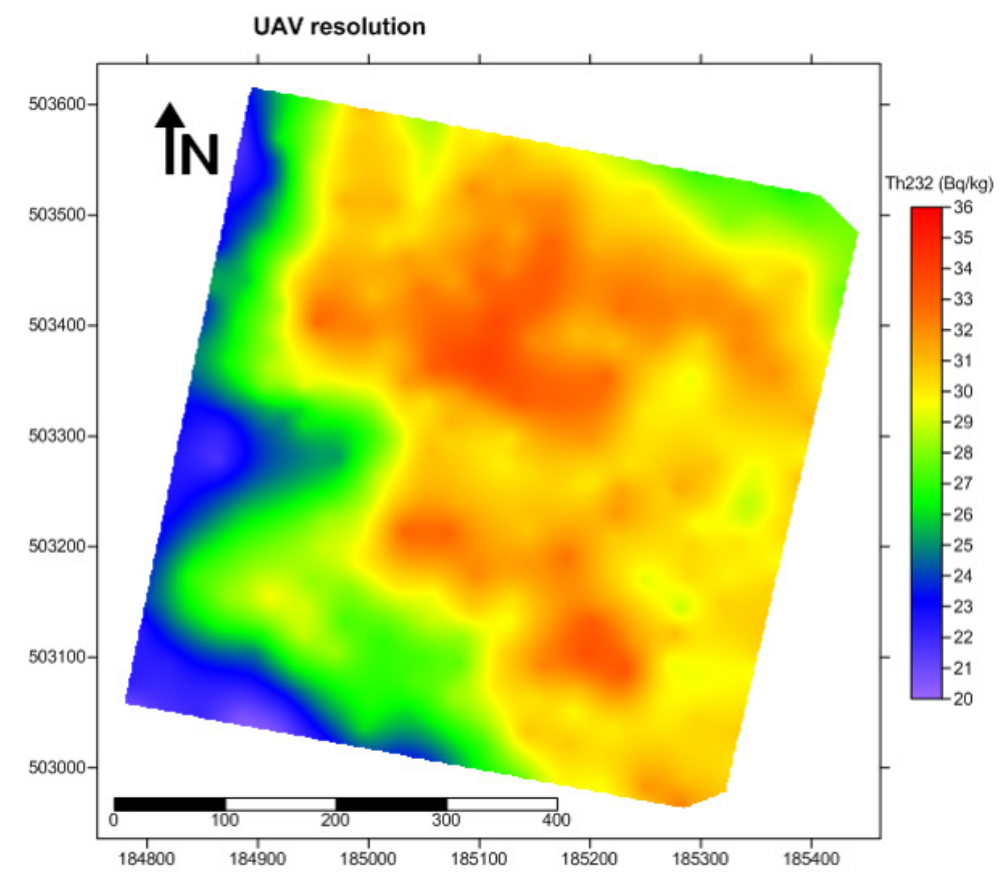

Figure 14: Interpolated ${ }^{232}$ Th map of UAV based measurements at UAV point density

\subsection{Calibration data}

\subsubsection{Local calibration}

For local calibration, 15 sample locations were selected. For calibration, it is advantageous when the samples are evenly spread over feature space. For spatial interpolation, this should also be the case for geographic space to reduce prediction error. Ideally these two goals could be satisfied by multiobjective optimization. However, due to budgetary limitations we took a simpler and more pragmatic approach by only optimizing the sampling locations in feature space and checked a posteriori if this was also the case in geographic space. The latter is not necessarily guaranteed, but in our case the locations were also nicely spread over the study area. For more information on calibration see Annex 1.

The samples were taken with a soil auger at 5 or 6 points at and around the GPS location over a depth of 0-30 cm and then mixed per sample location to approximate the gamma-ray spectrometer footprint and cancel out very short distance soil variation that is not relevant for this purpose. The sample was mixed, dried, crushed and sieved at CBLB, the soil chemical lab of Wageningen University and Research (WUR). This sample was subdivided. One subsample was analysed by CBLB on clay content, grain sizes (Dutch: zeefkromme) and soil organic matter using LDPSA (laser diffraction article size analysis) and loss on ignition (Dutch: gloeiverlies). The other subsample was measured on the concentrations of radionuclides by Medusa Explorations in a lab setup at a measuring time long enough to obtain a maximum statistical uncertainty $(1 \sigma)$ of $5 \%$.

\subsubsection{Regional calibration}

To test whether a regional dataset can be used for calibration of the measurements, a national calibration set, collected by Medusa Explorations, was used. This set consists of 150 samples throughout the Netherlands from different soil types with a majority from marine soils. This dataset is a collection of data from various projects. The samples were not collected with the aim of making a statistically valid dataset of the Netherlands and it cannot be regarded as a statistically based sample in Dutch soil feature and geographic space. 


\subsection{Validation data}

For validation, 44 samples were selected by means of stratified simple random sampling. The strata were the polygons of the $1: 50.000$ soil map of the Netherlands (Figure 6). Each strata was partitioned into compact geostrata by means of the spcosa-algorithm (Walvoort et al., 2010, 2018). A total of 22 geostrata were constructed. The purpose of the geostrata is to more evenly spread the samples over the study area. In each geostratum, two samples were selected randomly. This leads to a total of 44 samples for validation.

Samples were taken and analysed in the same way as the calibration samples (Section 3.3). 



\section{$4 \quad$ Results}

\subsection{Gamma radiation}

\subsubsection{Effect of elevation on signal strength}

The results in Table 1 present concentrations of radionuclides after analysis with the geometry dependent calibration files. If the calibration files (Section 2.2 and Section 3.2.3) are correct, the values should be equal. These data show that the mean values of the four radionuclides are similar for the UAV and ground-based measurements. The ${ }^{40} \mathrm{~K}$-concentrations of the ground-based measurements are $10 \%$ higher than the measurements of the UAV, for ${ }^{238} \mathrm{U}$ and ${ }^{232} \mathrm{Th}$ the average values between UAV and soil are the same. For ${ }^{137} \mathrm{Cs}$ the values of the UAV are $\pm 10 \%$ higher than the ground-based measurements. This means that calibration for elevation should be improved for the concentration of ${ }^{40} \mathrm{~K}$ and ${ }^{137} \mathrm{Cs}$. It also shows that the UAV measurements of ${ }^{238} \mathrm{U}$ and ${ }^{232} \mathrm{Th}$ give results that are equal to the ground-borne measurements.

Table 1: Average values and average of the errors per datapoint of the datasets measured from the ground and with the UAV.

\begin{tabular}{|c|c|c|c|c|c|c|c|c|c|}
\hline & $\begin{array}{c}\text { Repeated } \\
\text { average }\end{array}$ & $\begin{array}{c}40 \mathrm{~K} \\
(\mathrm{~Bq} / \mathrm{kg})\end{array}$ & $\begin{array}{c}238 \mathrm{U} \\
(\mathrm{Bq} / \mathrm{kg})\end{array}$ & $\begin{array}{c}\text { 232Th } \\
(\mathrm{Bq} / \mathrm{kg})\end{array}$ & $\begin{array}{c}137 \mathrm{Cs} \\
(\mathrm{Bq} / \mathrm{kg})\end{array}$ & sK & sU & sTh & sCs \\
\hline UAV & $10 \mathrm{~s}$ & 328 & 23.3 & 28.7 & 7.4 & 31.3 & 4.6 & 3.4 & 3.6 \\
\hline Ground & $4 \mathrm{~s}$ & 364 & 23.0 & 29.5 & 6.8 & 34.4 & 5.0 & 3.6 & 4.2 \\
\hline Ratio & & 0.90 & 1.01 & 0.97 & 1.09 & & & & \\
\hline
\end{tabular}

$\mathrm{s}=$ standard deviation

\subsubsection{Effect of elevation on footprint}

Figure 15 - Figure 18 show the interpolated maps. Each figure shows two maps; the left-hand figure represents the results of the UAV measurement, the right-hand figure represents the ground-based measurement.

MS1000 UAV results

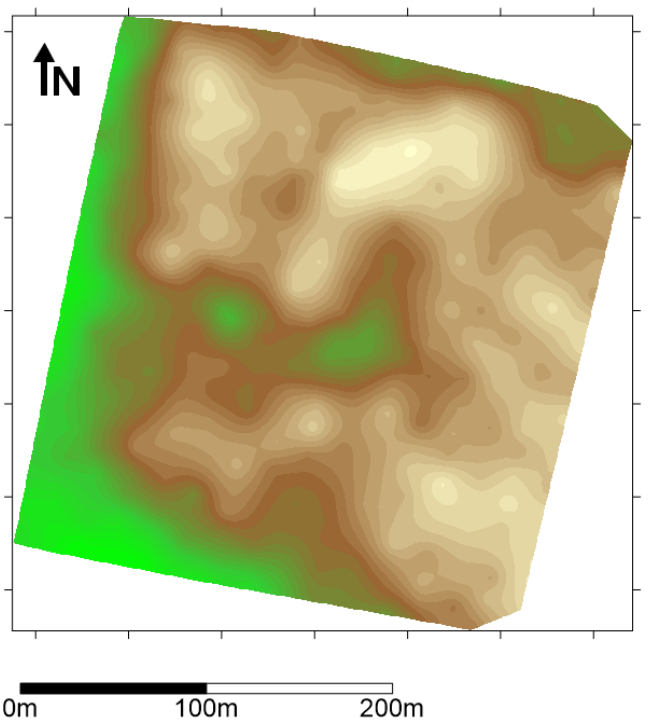

MS2000 walking results resampled to UAV positions

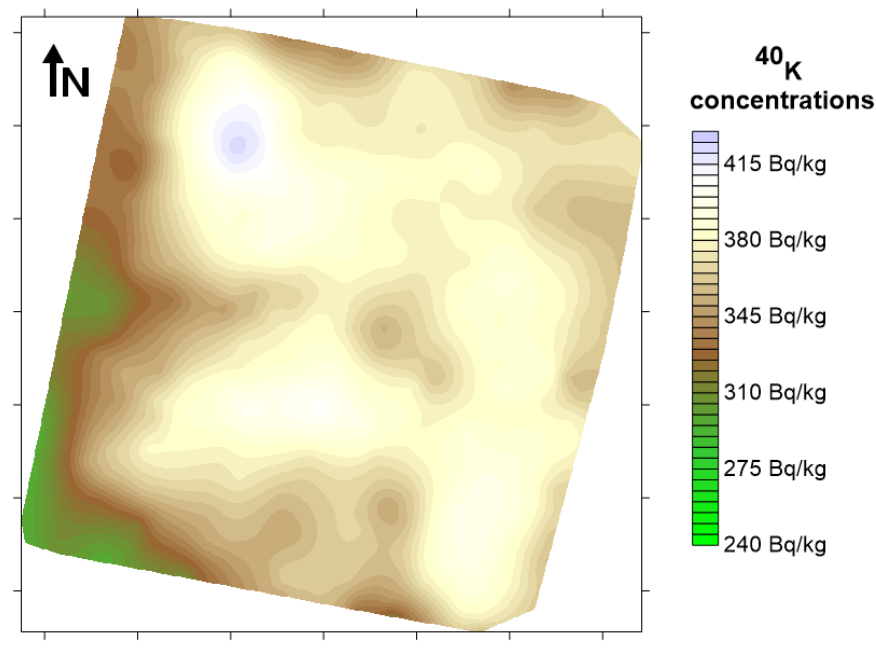

Figure 15: Nuclide concentrations found for ${ }^{40} \mathrm{~K}$. On the left the data recorded with a UAV, on the right the ground-based measurement 


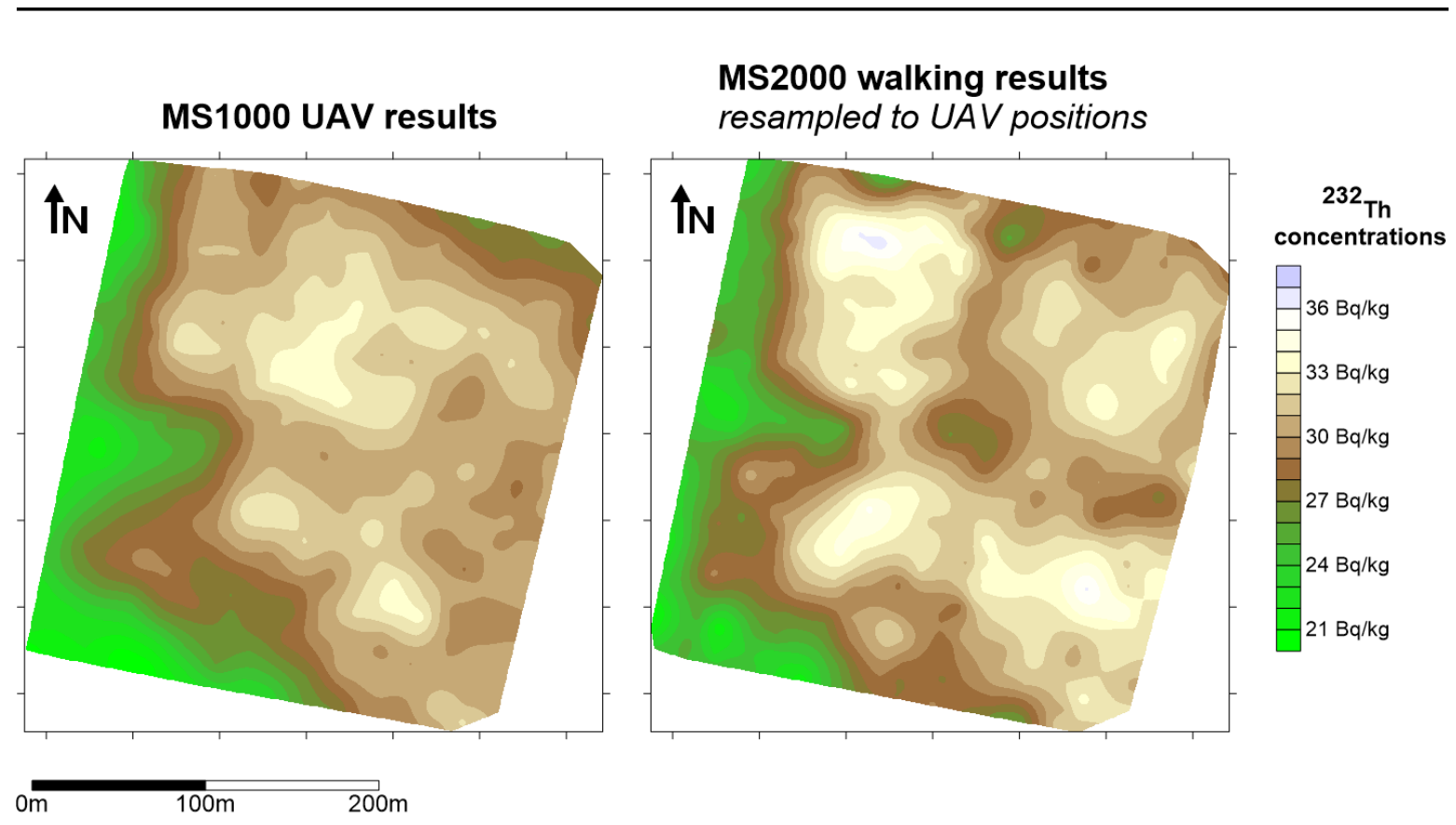

Figure 16: Nuclide concentrations found for ${ }^{232} \mathrm{Th}$. On the left the data recorded with a UAV, on the right the ground-based measurement.

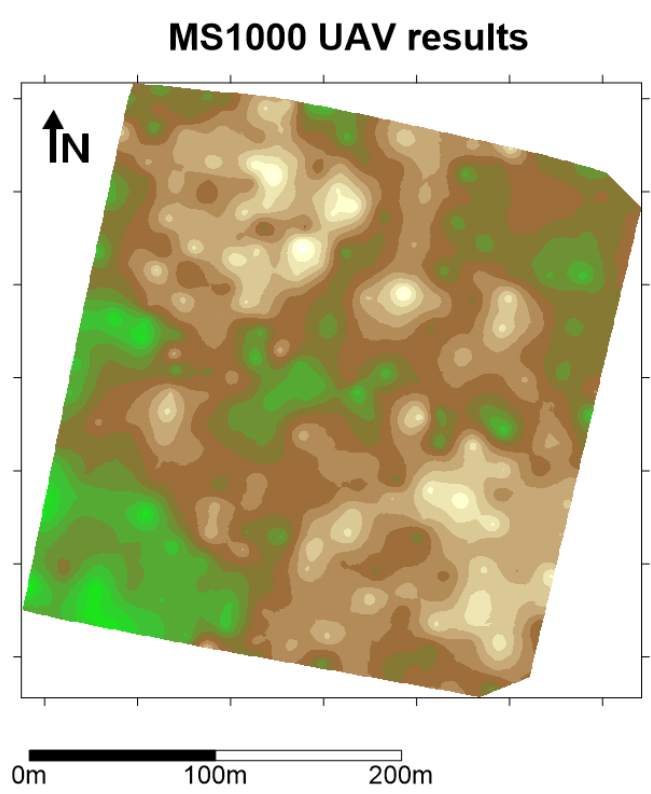

\section{MS2000 walking results} resampled to UAV positions

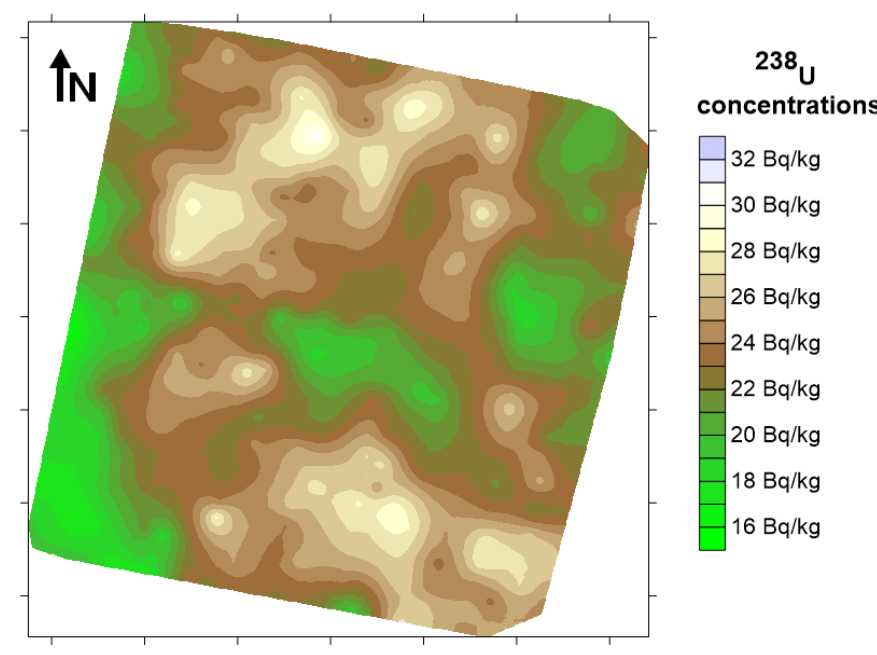

Figure 17: Nuclide concentrations found for ${ }^{238} \mathrm{U}$. On the left the data recorded with a UAV, on the right the ground-based measurement 


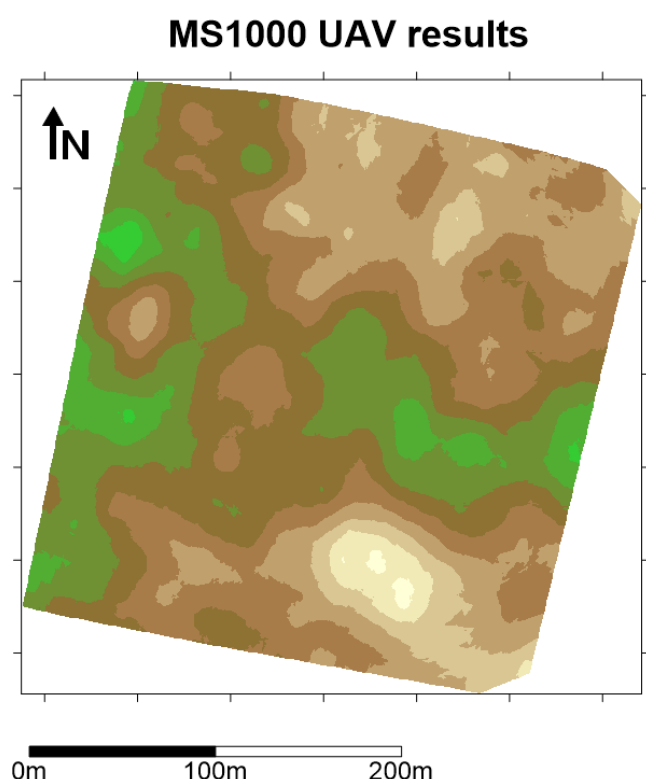

\section{MS2000 walking results}

resampled to UAV positions

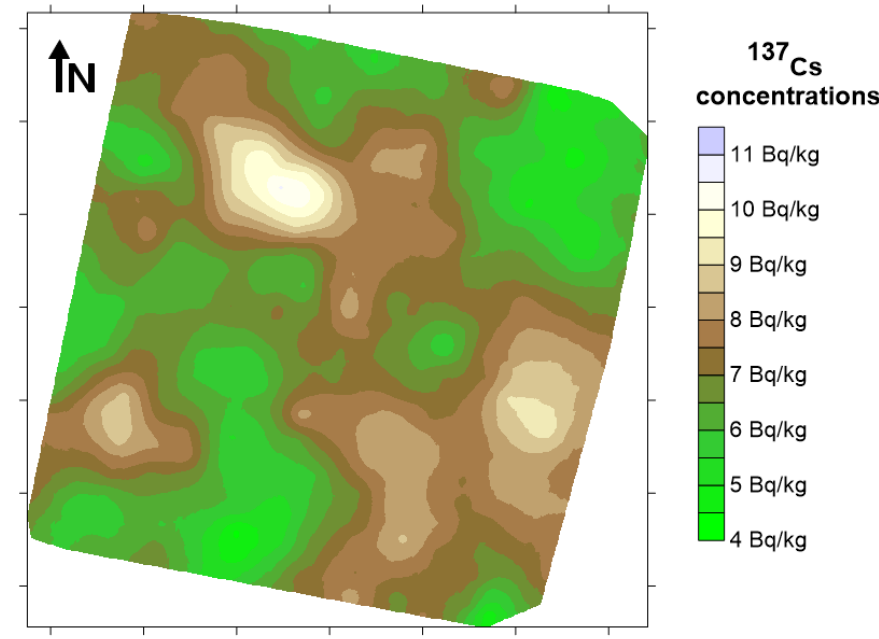

om

$100 \mathrm{~m} \quad 200 \mathrm{~m}$

Figure 18: Nuclide concentrations found for ${ }^{137} \mathrm{Cs}$. On the left the data recorded with a UAV, on the right the ground-based measurement.

These results show:

- Figure 15, potassium concentrations: the concentrations for potassium are lower in the UAV measurements. Visually, the structure of the ground-based measurement is largely comparable to the UAV based measurement.

- Figure 16, thorium concentrations: the concentrations for thorium corresponded well for both measurements. The structures are largely comparable although especially the locations of the higher concentrations do not match entirely (visual interpretation). The detail in the UAV based measurement seems slightly lower. This can be due to the difference in spatial support. The effect is not larger than $50 \mathrm{~m}$.

- Figure 17, uranium: the concentrations for uranium are comparable and the structures seem to be largely aligned. In the UAV measurements, more bulls eyes seem to occur. This could be due to interpolation.

- Figure 18, cesium concentrations: the concentrations for cesium differ. The UAV measurements are $10 \%$ higher. The structures do not match. This can be due to the low concentrations of cesium in Dutch soils and the relatively high measurement error.

The numerical comparison between UAV measurements and ground-based measurements shows that after data analysis the absolute concentrations for thorium and uranium match. The potassium concentrations of the UAV measurement are $10 \%$ lower than the ground-based measurement and cesium concentrations are $10 \%$ higher.

Why these differences occur with potassium and cesium and not with uranium and thorium will be further investigated in a PhD program initiated by Medusa Explorations and the University of Groningen (RuG).

A comparison of the mapped patterns (where all measurements are measured with a line spacing of $35 \mathrm{~m}$ ) shows that the expected effect of measurement height on spatial support as described in Section 2.2.2 is present but limited, although some questions remain. Not all patterns match between resampled walking and UAV measured. In general the ground-based measurements show a bit more spatial detail and variation than the UAV measurements at the same measurement density. The UAV measurements of the concentrations of thorium and uranium thus form a good alternative for groundbased measurements, although some variation in patterns as a result of a difference in spatial support should be expected. 
Since in this study the effect of measurement height was investigated, the results in this section are based on equal measurement density. The measurement density can be adjusted for both platforms depending on accuracy requirements of the results within the configuration constraints of the platforms.

\subsection{Soil texture}

There are several ways to translate gamma radiation measurements to soil property information ranging from simple statistical methods like linear regression to more complex methods like Support Vector Machines (SVM) (Knotters et al., 2017; Viscarra Rossel et al., 2007; Heggemann et al., 2018; Van der Klooster et al., 2011). The data requirements and suitability of the method vary and depend on the research (area) at hand. Because the calibration set in this research is small we chose to use linear regression.

Linear regressions were performed for clay content $(0-2 \mu \mathrm{m})$ and loam content $(0-50 \mu \mathrm{m})$ against the natural radionuclide concentrations as measured in the lab. Using more nuclides only slightly improved the accuracy of the results in linear regression. When applying PCA regression with all nuclides as input variables this further improved accuracy. Single correlations with texture were good for ${ }^{232} \mathrm{Th}$ (Table 2 and Figure 19) and better than with ${ }^{238} \mathrm{U}$. This corresponds with findings in literature (Mahmood, 2013; van der Klooster et al., 2011). Due to the challenges with the effect of elevation on some nuclides (Section 4.1) and the satisfactory results for ${ }^{232} \mathrm{Th}$, we chose to only use ${ }^{232} \mathrm{Th}$ for calibration at this point.

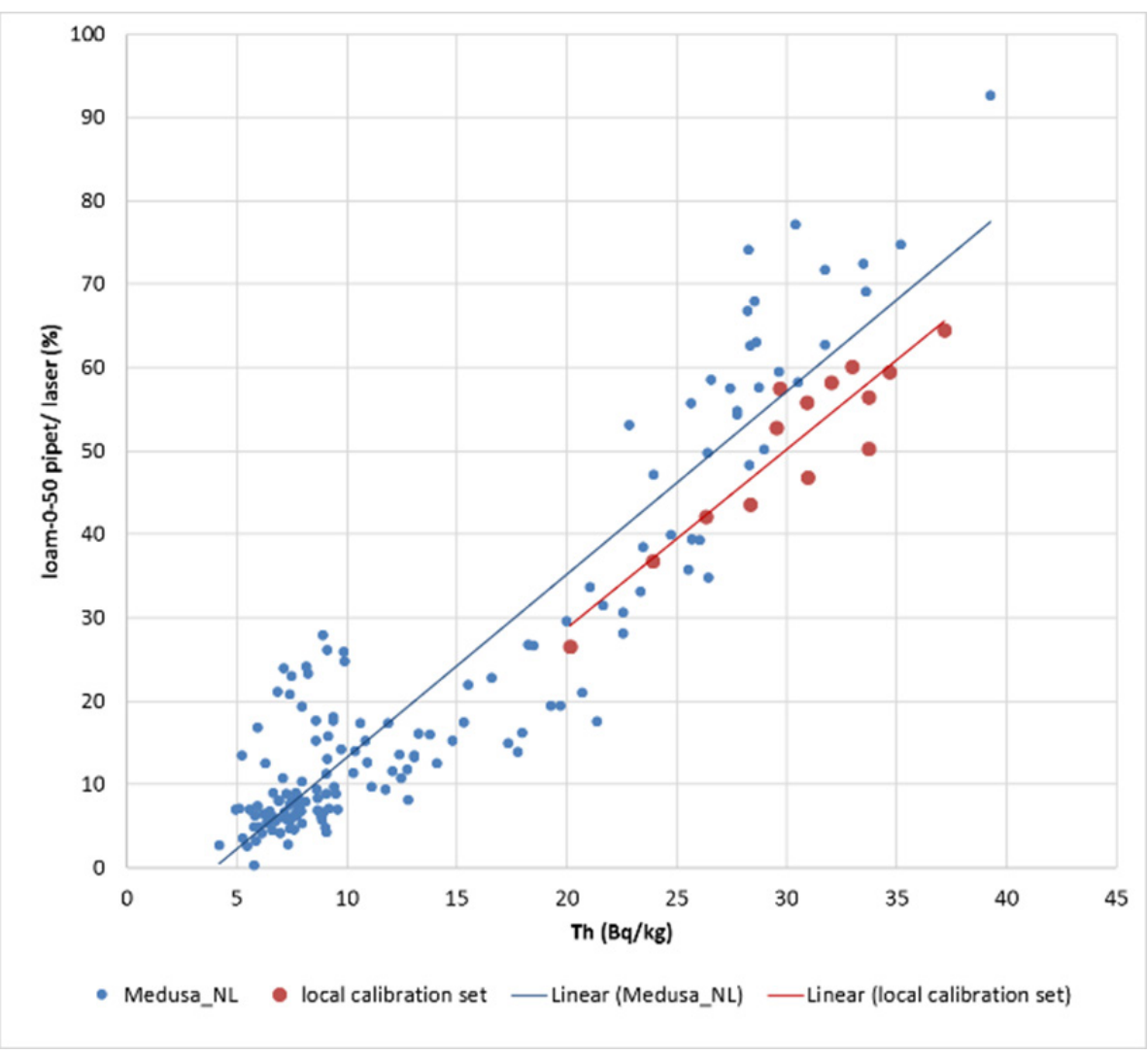

Figure 19: Correlation of local (red) and national (blue) calibration sets for loam and ${ }^{232}$ Th.

Table 2: Correlation between ${ }^{232}$ Th and soil texture for local and national calibration sets, represented by $R^{2}$.

\begin{tabular}{lll}
$R^{2}$ & Clay $\%(0-2 \mu m)$ & Loam \% $(0-50 \mu m)$ \\
Local & 0.62 & 0.84 \\
\hline National & 0.84 & 0.86 \\
\hline
\end{tabular}


Since the objective of this study is to assess the accuracy and costs associated with different measurement strategies (platform, sensor size, calibration), we applied the formulas derived with linear regression from the two calibration sets (local and national, see Section 3.3) to the maps of both platforms at their measurement density (Figure 12 and Figure 14) to derive soil texture maps (Figure 20). To compare the accuracies derived from different configurations of sensor measurement to conventional soil sampling, the average of the calibration samples was calculated and assigned to the entire study area (Figure 21).

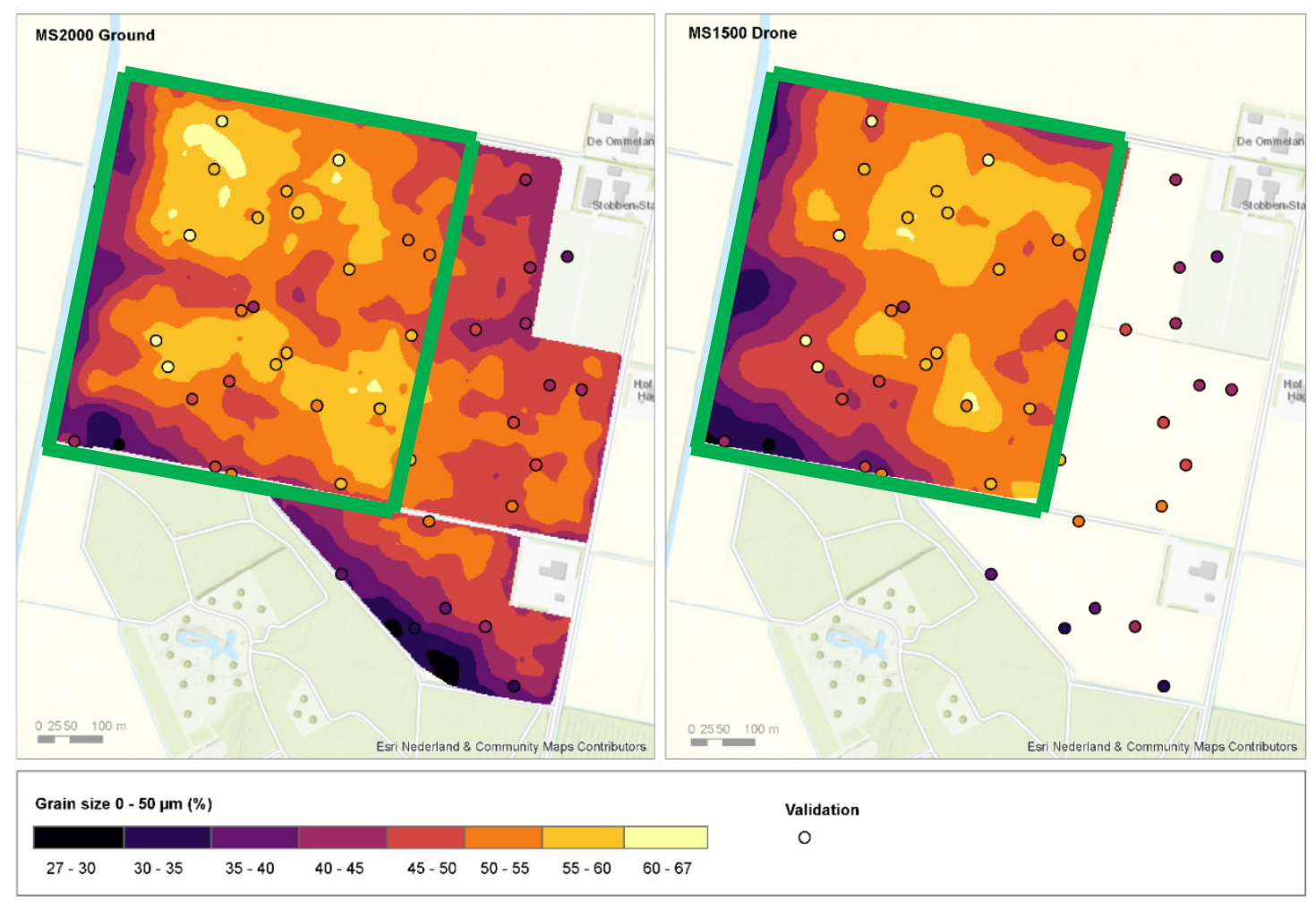

Figure 20: Loam \% maps of 0-30 cm depth as derived from local calibration regression formulas to ground-based gamma radiation maps (left) and UAV based gamma radiation measurements (right). The points are validation locations.

For each combination of platform height and sensor type validation statistics were calculated for soil texture (Table 3 and Table 4 ) to assess the effect of the different platforms on final results. The mean error (ME), a measure of bias or systematic error. The standard deviation of error (SDE) is a measure of random error or precision: small SDE's go with high precision. The median absolute error (MAE) is a measure of overall error or accuracy: small MAE's go with high accuracy. The correlation coefficient is a measure that indicates the extent to which the spatial variation is captured. A low coefficient indicates that spatial variation in the validation set is not represented in the tested map.

Table 3: Validation results for clay content $(0-2 \mu \mathrm{m})$. Values in \% clay. 'Local': the local calibration data were used. "Resampled": only ground gamma-ray spectrometer measurements that coincide with UAV measurements were used.

\begin{tabular}{lcccc} 
Clay \% $(0-2 \mu \mathrm{m})$ & Ground local & Ground resampled local & UAV local & Sample mean \\
Mean (systematic) error & 1.3 & 1.4 & 1.7 & 1.6 \\
\hline Precision (SDE) & 2.9 & 3.0 & 3.4 & 3.3 \\
\hline $\begin{array}{l}\text { Median absolute error (overall } \\
\text { accuracy) }\end{array}$ & 0.77 & 1.0 & 0.8 & 0.87 \\
\hline \begin{tabular}{l} 
Correlation coefficient \\
\hline
\end{tabular} & 0.4 & 0.3 & 0.1 & 0 \\
\hline
\end{tabular}


Table 4: Validation results for loam content $(0-50 \mu \mathrm{m})$. Values in \% loam. 'Local': the local calibration data were used. "Resampled": only ground gamma-ray spectrometer measurements that coincide with UAV measurements were used.

\begin{tabular}{lcccc} 
Loam \% (0-50 $\mathrm{mm})$ & Ground local & Ground resampled local & UAV local & Sample mean \\
$\begin{array}{l}\text { Mean (systematic) error } \\
\text { Precision (SDE) }\end{array}$ & 2.1 & 2.8 & 4.7 & 4.3 \\
\hline $\begin{array}{l}\text { Median absolute error (overall } \\
\text { accuracy) }\end{array}$ & 5.7 & 7.3 & 4.3 & 4.1 \\
\hline \begin{tabular}{l} 
Correlation coefficient \\
\hline
\end{tabular} & 0.8 & 4.9 & 0.0 & 5.9 \\
\hline
\end{tabular}

The results from Table 3 and Table 4 show that the extra spatial information from the gammaspectrometer improves the accuracy of the resulting maps compared to the sample mean. Both for clay and loam the ground-borne gamma-ray spectrometer predictions perform better than the sample mean. With less extra data points (ground resampled compared to ground), the uncertainty increases. The data quality of the UAV-borne measurements is comparable to the ground-borne measurements when an equal spatial resolution of data points is used. However, the higher spatial resolution of the ground borne measurements improves the uncertainty by $40 \%$ compared to using sample mean.

The spatial variation is not represented at all by the sample mean due to its nature. The spatial variation is captured by the gamma-ray spectrometer based maps, where the loam maps perform better than the clay maps. The ground-based maps with a high point density perform better than the resampled ground-based maps compared to the resampled ground-based maps due to their lower point density. The resampled ground-based maps for clay perform better than the UAV maps, for loam their performance is comparable. This analysis shows the difference in products (gamma-ray spectrometer based versus sample mean), and the effect of point density and spatial support on representing spatial patterns.

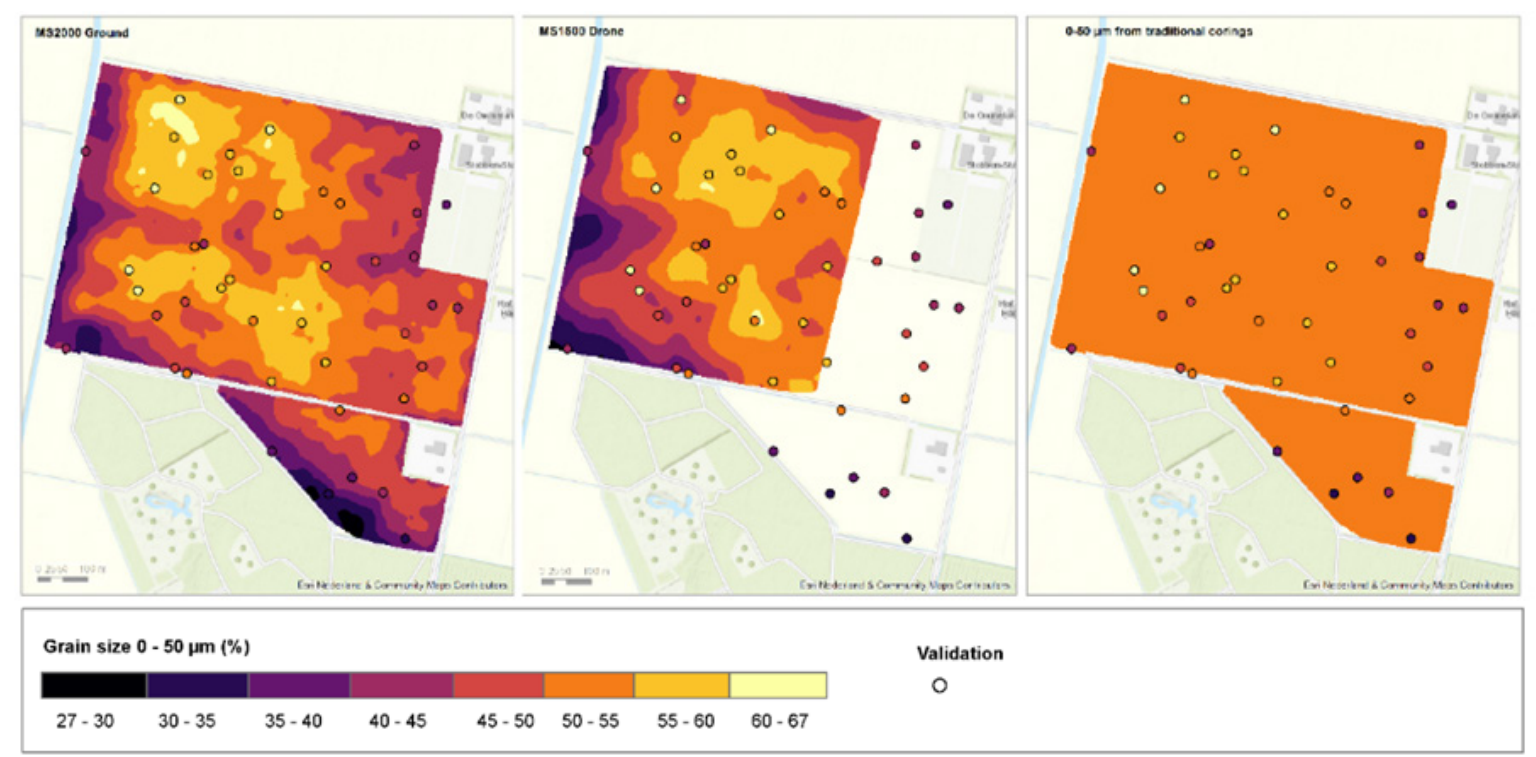

Figure 21: Maps of loam content produced with ground measurements (left), UAV measurements (centre) and areal mean of calibration data (right). The sample mean provides a different information product without spatial variation.

To assess the effect on accuracy of using different calibration sets (local and national, see Section 3.3), the validation statistics were calculated for loam content using the two calibration sets available. 
Table 5: Validation results for loam content $(0-50 \mu \mathrm{m})$. Values in \% loam. 'Local': the local calibration data were used. 'National': the national calibration data were used. "Resampled": only ground gamma-ray spectrometer measurements that coincide with UAV measurements were used.

\begin{tabular}{|c|c|c|c|c|c|c|c|}
\hline Loam \% (0-50 $\mu \mathrm{m})$ & $\begin{array}{c}\text { Ground } \\
\text { local }\end{array}$ & $\begin{array}{l}\text { Ground } \\
\text { national }\end{array}$ & $\begin{array}{c}\text { Ground } \\
\text { resampled } \\
\text { local }\end{array}$ & $\begin{array}{c}\text { Ground } \\
\text { resampled } \\
\text { national }\end{array}$ & $\begin{array}{l}\text { UAV } \\
\text { local }\end{array}$ & $\begin{array}{c}\text { UAV } \\
\text { national }\end{array}$ & $\begin{array}{c}\text { Sample } \\
\text { mean }\end{array}$ \\
\hline Mean (systematic) error & 2.1 & -11.8 & 2.8 & -9.9 & 4.7 & -6.5 & 4.3 \\
\hline Precision (SDE) & 5.7 & 16.8 & 7.3 & 15.6 & 9.3 & 12.3 & 10.0 \\
\hline Correlation coefficient & 0.8 & 0.8 & 0.6 & 0.6 & 0.6 & 0.5 & 0 \\
\hline
\end{tabular}

The results from Table 5 show that calibration using the national calibration set results in lower accuracies independent of the platform compared to using a local calibration set. Nevertheless, the differences in accuracies between the platforms as apparent in Table 3 and Table 4 are not visible for national calibration in Table 5. As a matter of fact, the accuracy increases for UAV borne measurements compared to ground-borne measurements and for resampled ground borne measurements compared to full point density ground-borne measurements. This can be a result of the size of the test set.

\subsection{Cost - benefit}

\subsubsection{Costs}

To gain insight into the costs of the different platforms and systems, and the different calibration methods for mapping soil texture of the layer $0-30 \mathrm{~cm}$, a specified overview was made (Table 6). It should be noted that this is an estimation based on current costs and optimal conditions. Therefore, the listed costs and differences are an indication only. In this study only measurements on foot have been executed for the ground-based application because the subsoil was not dry enough to allow a vehicle or crops were present on the field. In other circumstances a quadbike, tractor or 4WD car can often be used (Van Egmond \& Koomans, 2016).

Therefore, this application is included in the overview. Costs have been calculated at the maximum daily production, so no extra time has been taken into account to change fields for example. Prices are according to the costs of staff, instruments and labs in this study. Line spacing is an educated guess based on the spatial detail provided by the $1: 50.000$ soil map of the Netherlands. Total cost per hectare is based on calibration using the national dataset. Total cost per hectare including local calibration includes the costs for augerings as defined here. At present 15 samples per 50 hectare are assumed. The optimal number of samples will depend on the required accuracy and the variation in the area (feature space). The resulting data products are different for the augerings (field average) as compared to the sensor results (spatially explicit) and are therefore not comparable.

In the estimate of the UAV we assumed the system that was used in the pilot study. With this system, $3 \mathrm{~m} / \mathrm{s}$ can be flown under good conditions, but a battery pack must be changed every 10 minutes. As a result, the daily production is relatively low. However, the technical abilities of UAVs are developing fast. In France the same spectrometer ( $6 \mathrm{~kg}$ payload) was flown with a gas-powered UAV which allows 2-3 hours flight time (Van der Veeke, 2018). This is not allowed to be operated in the Netherlands yet, but due to the longer flight time we expect an efficiency improvement of a factor 2, with which the costs of the UAV measurements come close to the quad bound measurements.

Table 6 shows that the costs for flying a UAV are about 2 times higher than the costs when using a vehicle. This is mainly due to the lower daily production of a UAV. Still, the costs for an application on foot are twice the costs for UAV measurements due to the achievable daily production. 
Table 6: Specification of costs per platform

\begin{tabular}{|c|c|c|c|c|c|c|}
\hline \multirow[b]{2}{*}{ Costs per day } & \multicolumn{2}{|c|}{ UAV } & Car-borne & Walking & \multicolumn{2}{|c|}{ Augerings } \\
\hline & & 1250 & 1200 & 950 & & 1200 \\
\hline Person & & 600 & 400 & 400 & & 1000 \\
\hline Sensor & & 350 & 350 & 350 & & \\
\hline Platform & & 100 & 250 & & & \\
\hline Travel costs & & 200 & 200 & 200 & & 200 \\
\hline Data analysis & & 800 & 800 & 800 & & 0 \\
\hline Cost of calibration 50 ha* & & 0 & 0 & 0 & & 2685 \\
\hline Sampling costs & & & & & & \\
\hline Sample analyses & & & & & & 2685 \\
\hline Daily production (km) & & 30 & 65 & 15 & & \\
\hline Line spacing $(\mathrm{m})$ & & 50 & 50 & 50 & & \\
\hline Daily production (ha) ${ }^{* *}$ & & 150 & 325 & 75 & & 50 \\
\hline Costs of measurement/ha & & 8 & 4 & 13 & & 24 \\
\hline Costs of analysis/ha & & 5 & 2 & 11 & & 0 \\
\hline Cost of regional calibration/ha & & 0 & 0 & 0 & 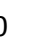 & 54 \\
\hline Cost of local calibration & & 54 & 54 & 54 & & 54 \\
\hline total cost/ha & $€$ & 14 & $€$ & 23 & $€$ & 78 \\
\hline total cost/ha incl local calibration & $€$ & 67 & $€$ & 77 & $€$ & 78 \\
\hline
\end{tabular}

* 15 samples for 50 ha

** based on $50 \mathrm{~m}$ line spacing

\subsubsection{Operational differences/benefits}

Different terrain can require different platforms due to accessibility and trafficability. Therefore, this should also be taken into account when assessing the cost benefit trade off of an application. See operational limitations and advantages of the various platforms in Table 7).

Table 7: Operational characteristics of the different platforms.

\begin{tabular}{|c|c|c|c|c|}
\hline & Accessibility & Trafficability & Legislation & Spatial support \\
\hline Corings & $\begin{array}{l}\text { Moderately dependent } \\
\text { on access roads, fences, } \\
\text { ditches }\end{array}$ & Walkable & None & $4 m^{2}$ \\
\hline Walking & $\begin{array}{l}\text { Moderately dependent } \\
\text { on access roads, fences, } \\
\text { ditches }\end{array}$ & $\begin{array}{l}\text { Walkable, vegetation } \\
\text { low }\end{array}$ & None & $6 \mathrm{~m}^{2}$ \\
\hline Driving & $\begin{array}{l}\text { Dependent on access } \\
\text { roads, all fences, ditches }\end{array}$ & $\begin{array}{l}\text { Dependent on dry top } \\
\text { and subsoil; no crops at } \\
\text { surface/planted; }\end{array}$ & $\begin{array}{l}\text { Not allowed during bird } \\
\text { breeding periods; } \\
\text { floodplains cannot be } \\
\text { accessed in specific time } \\
\text { periods }\end{array}$ & $5-8 \mathrm{~m}^{2}$ \\
\hline UAV & $\begin{array}{l}\text { Operator must reach } \\
\text { central location to retain } \\
\text { line of sight with UAV, } \\
\text { trees can hamper sight }\end{array}$ & $\begin{array}{l}\text { Not during rain or } \\
\text { strong winds }\end{array}$ & $\begin{array}{l}\text { No-fly zones around } \\
\text { airports, roads, built up } \\
\text { area }\end{array}$ & $2200 \mathrm{~m}^{2}$ \\
\hline
\end{tabular}

Due to these operational differences the potential and daily production of the different platforms will (strongly) depend on the area that is to be measured. Based on topographic data and the above an assessment of the potential average costs and possibilities per platform would be possible per landscape region in the Netherlands. 


\section{Discussion, conclusions and recommendations}

\subsection{Discussion}

The objective of this study was to assess the possibility, accuracy and costs associated with different measurement strategies (platform, sensor size, calibration scale) for measuring soil texture in the topsoil $(0-30 \mathrm{~cm})$. This was subdivided in the following research questions in Section 1.2:

1. Is it possible to mount a gamma-ray spectrometer under a UAV to survey soil texture?

2. What is the quality of the UAV borne data compared to a ground-borne survey and normal soil sampling $(0-30 \mathrm{~cm})$ :

a. In spatial resolution?

b. In accuracy of the predicted clay content?

3. How do survey costs compare between different measurement strategies (platform, sensor size, calibration scale) for measuring soil texture in the topsoil $(0-30 \mathrm{~cm})$ ?

4. What is the practical advantage of a UAV survey compared to other methods?

5. What would be an adequate strategy to choose platform, sensor, survey specifications and analysis for $0-30 \mathrm{~cm}$ soil texture mapping?

The results of the research conducted to answer these questions is discussed here.

\section{Possibility and accuracy of UAV borne gamma-ray spectrometer measurements versus ground-borne}

Gamma radiation was measured using different platforms and local and national calibration data. The measurements were used to map soil texture of the top soil layer $(0$ to $30 \mathrm{~cm}$ ) as described in Chapter 4. This provides information and insight into various aspects of the setup, measurements and potential.

The results show that the analyses provide reasonable estimates of ${ }^{232} \mathrm{Th}$ and ${ }^{238} \mathrm{U}$ concentrations and patterns, but differences occur in ${ }^{40} \mathrm{~K}$ and ${ }^{137} \mathrm{Cs}$ concentrations (Section 4.1) and more research is needed to improve on calibration of the gamma-ray measurements.

The differences in validation results for clay and loam between ground-based, ground-based resampled and UAV based applications (Table 3 and Table 4) show that not just point density but also spatial support influences the decrease in accuracy and representation of spatial variation for UAV compared to ground-based measurements. To better understand and be able to correct for these effects more research is needed into the exact effects of elevation on the gamma radiation signal. This is currently performed in a PhD research at Medusa Explorations by Steven van der Veeke. On the whole however the accuracies and capture of spatial variation of the ground-based and UAV validation results are largely comparable, indicating that the quality of the UAV measurements is largely comparable to ground measurements. This indicates that UAV is a viable platform for gamma radiation measurements to map soil texture.

Analysis of the validation results with respect to the use of local or national calibration data clearly showed that local calibration systematically outperforms national calibration in this study (Table 5). The differences in precision and accuracy are larger than they are when comparing the effects of the platform used. It should be noted that the national dataset used here contains data from a limited number of soil geographic situations and it should be expected that a larger and more diverse dataset will give better results, perhaps in combination with alternative statistical methods which were not used here due to the small dataset and area. This is demonstrated by Heggemann et al. (2018), Coulouma et al. (2016) and to a certain extent Van der Klooster et al. (2011) and Van Egmond et al. (2010). 
Analysis of the validation results with respect to the use of locally or nationwide collected calibration data indicated that if the national set is used the ground-based measurements are not more accurate than the UAV based measurements, despite the higher point density. If the local calibration set is used, however, the ground-based measurements have indeed a higher accuracy than the UAV based measurements. It is not yet clear what causes these differences, but we can conclude that measurements with small spatial support benefit from local calibration while UAV based measurements with larger spatial support, in this study do not.

Overall, the results shows that gamma radiation measured at different platforms is able to estimate various soil texture fractions at field level with high resolution.

\section{Cost benefit discussion}

The above two conclusions are mirrored by the results of the indicative cost analysis (Section 4.3.1), where the difference in cost between platforms is significant, a factor 2 to 3 . Where driving is cheaper than flying a UAV is cheaper than walking. This is not caused by instruments, but mainly by the daily production the three platforms can realise in good circumstances.

A much larger cost difference is apparent between local and library (i.e. national) calibration. The cost effect of taking and analysing new samples instead of using a library on the price per hectare is a factor 3 to 10 . Of course it should be noted that the number of samples and lab analysis costs influence costs to a large extent. Therefore it is worthwhile to investigate the minimum amount of samples needed to maintain accuracy, to spike a library with just a few local samples and to try to reduce lab costs. It is also important to assess whether the research question at hand demands a high accuracy or if a library or national calibration can be used since this greatly reduces overall costs. Depending on the size of the mapping effort and/or the number of useful applications it can be worthwhile to build a Dutch gamma spectral calibration library that covers a large variety of soil geographic situations.

Although validation results and the costs for the sample mean of the calibration samples are depicted in the same tables as the sensor based results for comparison, it should be noted that they provide significantly different information, they do not provide any information about the spatial pattern or distribution. This is illustrated in Section 4.2.

The practical application of the platforms differs significantly (Section 4.3.2) and the temporal or spatial terrain characteristics and measurement circumstances at hand may exclude some platforms. The benefits of each platform should therefore be reviewed. Before balancing a trade-off between accuracy and costs it is important to take this into account.

\section{Adequate procedure to select appropriate measurement strategy}

The above implies a trade-off between accuracy, costs, supplying detailed spatial information and the depth requirements of the results $(0-30 \mathrm{~cm}$ or deeper). There are methods in development that aim to assist this trade-off by calculating a fitness-for-use or an added value of information (De Bruin et al., 2001; Knotters and Vroon, 2015; Nijbroek et al., 2018). This can perhaps be applied in a follow-up of this study.

To navigate this trade-off based the presently available data for any given research question, it seems sensible to first choose the required accuracy and spatial detail, then assess the terrain and its limitations. This will then result in a choice for a platform, which will in turn determine the choice between locally collected calibration data or a nationwide calibration library. This holds true for applications in the $1: 50.000$ soil map of the Netherlands as well as in smaller scale applications such as precision agriculture, nature conservation and spatial planning. 


\subsection{Conclusions}

Mapping soil texture of the layer $0-30 \mathrm{~cm}$ with gamma radiation and testing the effects of different platforms, systems and calibration sets in a study area of 40 hectares in Flevoland, the Netherlands was successful and has resulted in the following conclusions:

- Within the context of this study a self-supporting and autonomous functioning lightweight gammaray spectrometer was developed that weights $6 \mathrm{~kg}$, making it a viable sensor for commercially available UAVs. This sensor was successfully tested in this study.

- The tests and analysis performed in this study show promising results but more research is needed to fully account for the effects of elevation differences on the radiation measurements.

- UAV measurements are more expensive but UAVs can access terrain with crops, low trafficability, fences and which are less accessible by roads.

- Ground-based measurements are cheaper in accessible areas and in areas that are less accessible to drones (e.g. trees, near airfields, roads).

- The temporal applicability of the platforms may differ.

- The costs mainly depend on the choice between calibration with locally collected data or calibration with data from a nationwide library.

- Accuracy depends more on the calibration data used than on platform, with use of locally collected calibration data being more accurate.

- For any given research question, first assess the required accuracy, measurement depth and spatial detail, then shortlist the possibilities and choose a suitable platform which implies the calibration scale and method within budget limits.

- A national gamma radiation (nuclide compressed) library, a calibration dataset that contains data from a large variety of soil geographic situations, will greatly reduce costs of gamma radiation mapping for soil mapping in the Netherlands.

\subsection{Recommendations}

We recommend for any given research question, to first assess the required accuracy, measurement depth and spatial detail, then shortlist the possibilities and choose within budget limits a suitable platform, which determines the choice between local or nationwide calibration data.

As a national gamma radiation (nuclide compressed) library, a calibration dataset that contains data from a large variety of soil geographical situations, will greatly reduce costs of gamma radiation mapping for soil mapping in the Netherlands we recommend to start one in a low cost but effective way by measuring current representative sample collections of Wageningen Environmental Research on gamma radiation.

We recommend investigating the effect of elevation on gamma radiation measurements further with the aid of computer simulations and additional field measurements. This is addressed by a PhD project at Medusa Explorations and RuG by Steven van der Veeke. 



\section{References}

Coulouma, G., L. Caner, E.H. Loonstra, P. Lagacherie (2016). Analysing the proximal gamma radiometry in contrasting Mediterranean landscapes: Towards a regional prediction of clay content. Geoderma 266: 127-135.

De Bruin, S., A. Bregt and M. van de Ven (2001). Assessing fitness for use: the expected value of spatial data sets. International Journal of Geographical Information Science 15 (5): 457-471.

De Vries, F., D.J. Brus, B. Kempen, F. Brouwer and A.H. Heidema (2014). Actualisatie bodemkaart veengebieden; Deelgebied 1 en 2 in Noord Nederland. Wageningen, Alterra Wageningen UR (University \& Research centre), Alterra-rapport 2556.

Everts, F.K., S. Wolters, K. van Bohemen, C. van Dijk (2018). D1.6 Final Report on Research Results, Research Projects and Industry Solutions, Smart AKIS project, funded by EU H2020. To be published soon on www.smart-akis.com.

Heggemann, T., G. Welp, W. Amelung, S. Koszinski, M. Leenen, K. Schmidt, S. Pätzold (2018). High resolution texture estimation for precision farming via mobile gamma spectrometry. Proccedings BonaRes conference 26-28 February Berlin, Germany.

Hendriks, P. H. G. M., J. Limburg, R.J. de Meijer (2001). Full spectrum analysis. Environmental Radioactivity 53: 365-380.

Kempen, B. (2011). Updating soil information with digital soil mapping. PhD Thesis, Wageningen University.

Kempen, B., F. Brouwer, D.J. Brus, M. Pleijter and F. de Vries (2011). Validatie Bodemkaart Veengebieden provincie Utrecht, schaal $1: 25$ 000. Wageningen, Alterra, Alterra-rapport 2252.

Knotters, M. en H.R.J. Vroon (2015). The economic value of detailed soil survey in a drinking water collection area in the Netherlands. Geoderma Regional 5: 44-53.

Knotters, M., F.M. van Egmond, G. Bakker, D.J.J. Walvoort, F. Brouwer (2017). A selection of sensing techniques for mapping soil hydraulic properties; , Wageningen, Alterra, WEnR Report 2853. 69 blz.; 21 fig.; 21 tab.; 16 ref.

Mahmood, H. S. (2013). Proximal soil sensors and data fusion for precision agriculture. PhD thesis, Wageningen University, Wageningen, NL: 205.

Nijbroek, R., K. Piikki, M. Söderström, B. Kempen, K.G. Turner, S. Hengari en J. Mutua (2018). Soil organic carbon baselines for land degradation neutrality: map accuracy and cost tradeoffs with respect to complexity in Otjozondjupa, Namibia. Sustainability 2018,10,1610; doi:10.3390/su10051610.

Van der Graaf, E.R., Limburg, J., Koomans, R.L. and Tijs, M. (2011). Monte Carlo based calibration of scintillation detectors for laboratory and in situ gamma ray measurements. Journal of Environmental Radioactivity, 102: 270-282.

Van der Klooster, E., F.M. van Egmond, M.P.W. Sonneveld (2011). Mapping soil clay contents in Dutch marine districts using gamma-ray spectrometry. European Journal of Soil Science 62(5): 743-753.

Van Egmond, F.M., R.L. Koomans (2016). Multi Sensor Soil Sensing Tool for Farmland in Spain. Proceedings Near Surface Geoscience EAGE 4-8 September 2016, Barcelona, Spain.

Van Egmond, F. M., E.H. Loonstra, J. Limburg, 2010. Gamma Ray Sensor for Topsoil Mapping: The Mole. In: Proximal Soil Sensing, Progress in Soil Science 1 R.A. Viscarra Rossel et al. (eds.), DOI 10.1007/978-90481-8859-8_27, Springer Science+Business Media B.V: p. 323-332.

Viscarra Rossel, R.A. H.J. Taylor, A.B. McBratney (2007). Multivariate calibration of hyperspectral gammaray energy spectra for proximal soil sensing". European Journal of Soil Science 58(1): 343-353.

Walvoort, D.J.J., Brus, D.J. and de Gruijter, J.J. (2010). An R package for spatial coverage sampling and random sampling from compact geographical strata by k-means Computers \& Geosciences 36: 2611267. http://dx.doi.org/10.1016/j.cageo.2010.04.005.

Walvoort, D.J.J, D.J Brus, and J.J de Gruijter (2018). Spatial Coverage Sampling and Random Sampling from Compact Geographical Strata. R package version 0.3-8. https://CRAN.R-project.org/package=spcosa 



\section{Justification}

This study was carried out as part of the project 'BRO Sensoren en Satellieten' which was granted to Wageningen Environmental Research by the Ministry of Agriculture, Nature and Food Quality. This project aims to address, investigate and apply possible innovations in the continuous actualisation of soil related registry objects in the Dutch Key Register of the Subsurface (BRO).

The contents of this report has been reviewed by Joop Okx, Dennis Walvoort and Mirjam Hack (all Wageningen Environmental Research). 



\section{Annex 1 Selection of sampling locations for calibration}

To spread 15 calibration samples evenly over feature space the original $\mathrm{K}, \mathrm{U}$, and Th data were standardized to zero mean and unit variance to give $\mathrm{K}, \mathrm{U}$, Th equal weight. Next, principal component analysis was applied to remove correlation. The principle component scores were subsequently partitioned into 15 clusters by means of k-means clustering. The 15 exemplars, i.e., locations that are nearest to each cluster centre, were selected as calibration location.

This resulted in 15 calibration locations that were evenly distributed in feature space. Figure A1.1 shows all sensing locations in feature space spanned by principal component axis (PC1, PC2, PC3). The circles are the cluster centres. The letters are the exemplars and were selected as calibration locations.

Figure A.1.2 shows a mapping of the original three dimensional feature space $(K, U, T h)$ to a plane by means of multidimensional scaling (Sammon's MDS). This mapping confirms that the locations are evenly distributed in feature space.

Figure A.1.3 shows the location of the calibration points in geographic space. Although, not necessarily guaranteed, the calibration locations are also evenly distributed in geographical space.
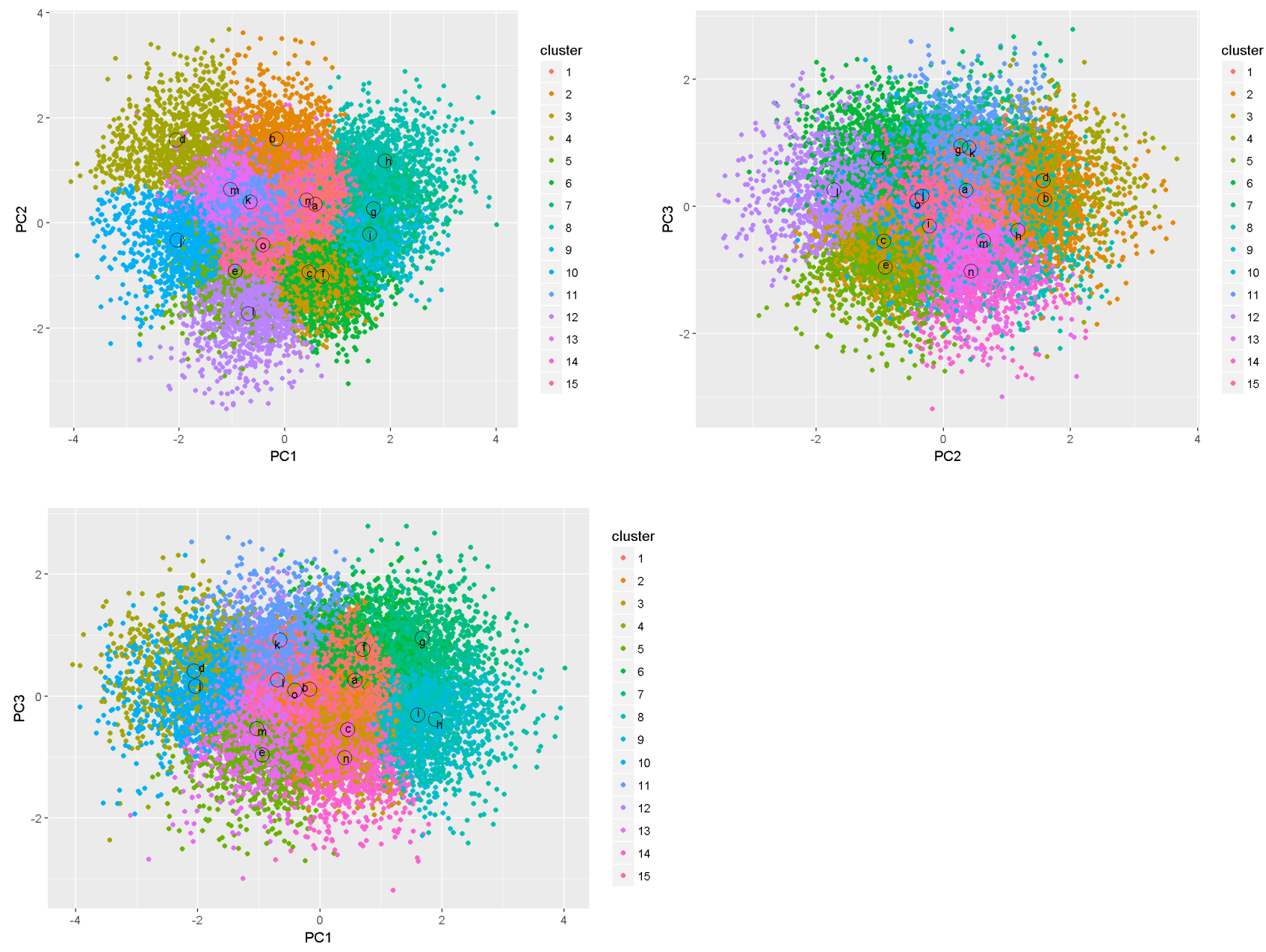

Figure A.1.1: Calibration samples in principle component feature space. 


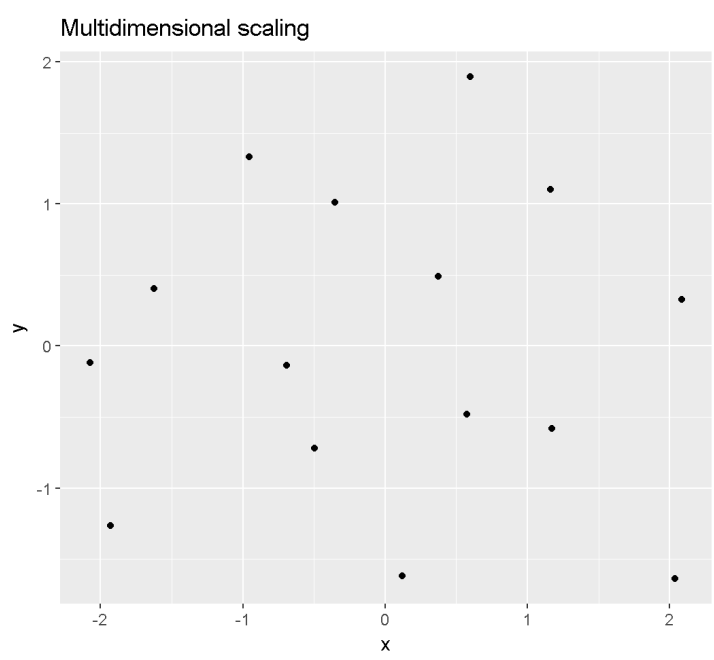

Figure A.1.2: Mapping of original three dimensional feature space $(K, U, T h)$ to a plane by means of multidimensional scaling (Sammon's MDS).

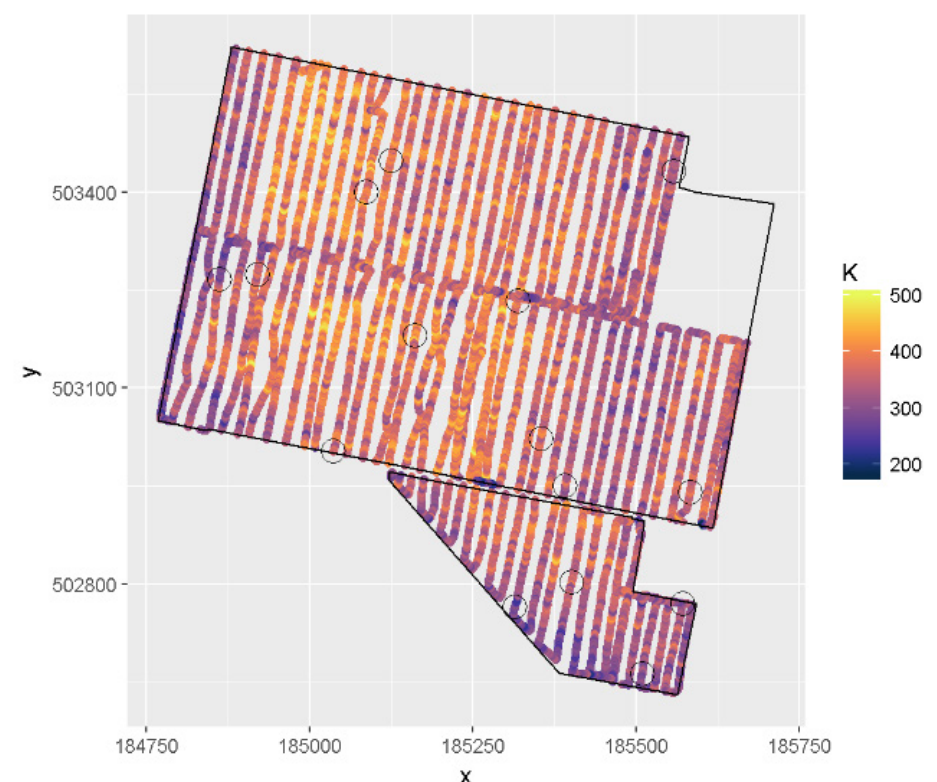

Figure A.1.3: Location of the calibration points in geographic space. 


\section{Annex 2 Set up of a validation experiment}

This Annex is a reprint of Appendix 1 in: M. Knotters, F.M. van Egmond, G. Bakker, D.J.J. Walvoort, F. Brouwer (2017) - A selection of sensing techniques for mapping soil hydraulic properties; , Wageningen, Alterra, WEnR Report 2853. 69 blz.; 21 fig.; 21 tab.; 16 ref

\section{A2.1 Selection target variables and measurement devices}

The primary focus in this validation experiment is on the performance of $Y$-ray spectroscopy in the spatial prediction of variables that are used in pedo-transfer functions for the Mualem-Van Genuchten parameters: clay, silt and sand content and median grain size of sand fraction (M50). The $\gamma$-ray device will be applied close to the ground surface using a quad and at various heights above the ground surface using a UAV, to evaluate the prediction performance in areas that are not accessible with a quad. The validation experiment can be extended to evaluation of the performance of near infrared spectrometry in the spatial prediction of organic matter content, clay, silt and sand content and median grain size of sand fraction (M50)

\section{A2.2 Selection of a study area}

\section{A2.2.1 Method}

A study area for testing several types of proximal sensors was selected according to the following general requirements:

1. The study area should be part of Oostelijk Flevoland;

2. The areas should be contiguous;

3. Land-use should be a mixture of agriculture and nature (including forest);

4. The study are should have a wide range of soil properties (organic carbon, clay content, loam content, M50, bulk density), varying from low to high. There should be sufficient spatial variation at short distances in the target variables.

Note that the availability of forests has been superseded because these areas are problematic for both quads and UAVs.

The following additional requirements for the use of UAVs were obeyed in the selection of a study area:

1. No built up area;

2. At least $10 \mathrm{~km}$ from an airport;

3. At least $50 \mathrm{~m}$ from $80 \mathrm{~km}$ roads;

4. At least $150 \mathrm{~m}$ from highways;

5. At least $150 \mathrm{~m}$ from high voltage pylons and high voltage lines.

The size of the study area depends on the available time to collect data by using a UAV and line spacing of flight lines. Thus the study area should not exceed 45 to 60 hectares.

The following selection procedure has been applied:

6. Download the most recent version of the topographic map scale 1:10.000;

7. Select all regions that should potentially be included (vector map A);
a. select agricultural areas;
b. select nature areas;
c. combine these areas. 
8. Select all regions that should be excluded (vector map B):

a. select all features listed above (e.g., built-up, airports, roads, highways, ) that are in the middle of no-go-areas;

b. buffer all these features with the specifications given above (e.g., a buffer of 150 meters on both sides of highways);

c. combine all buffers to get a map of all areas that should be excluded (no-go areas).

9. Remove all areas in vector map A that are part of vector map B. The result is vector map C;

10. Rasterize the soil map 1:50.000, the map of groundwater table classes 1:50.000, and the land-use map $1: 50.000$ for all polygons in map C (rasters are currently more convenient than vector maps for the analysis below);

11. Compute a heterogeneity index for each pixel in map C. Areas where this index is high, are potentially interesting study areas.

The soil map 1:50.000, the map of groundwater table classes 1:50.000 and the land-use map 1:50.000 were combined by assigning an integer value to each unique combination of soil type, water table class and land-use category. Next a heterogeneity index was calculated for each pixel by the normalized Shannon entropy $\mathrm{Hn}$, which is calculated as follows:

$$
\mathrm{H}=-\sum_{\mathrm{i}=1}^{\mathrm{n}} \mathrm{p}_{\mathrm{i}} \log _{2}\left(\mathrm{p}_{\mathrm{i}}\right)
$$

where $p_{i}$ is the probability of a specific class, in this case a combination of soil type, water table class and land-use category. The total number of classes equals $n$. The normalized Shannon entropy is given by:

$$
\mathrm{Hn}=\mathrm{H} / \mathrm{Hmax}
$$

where $H_{\max }=\log _{2}(n)$ is the maximum entropy. For each pixel, the normalized Shannon entropy is computed based on a search radius of about 357 meters around each pixel, i.e., an area of 40 hectares.

Not only the entropy of the area is important, also its acreage, since we do not prefer a study area that consists of a lot of small patches. Contiguity is therefore also an important selection criterion and is calculated for each pixel as the area of patches in a search radius of $357 \mathrm{~m}$, with a theoretical maximum of 40 hectares. An entropy of 0.35 and an acreage of 35 hectares were used as thresholds in selecting candidate pixels. Since the candidate pixels appeared to be located in clusters the $k$-mean algorithm was used to calculate the centers of the clusters. Next the study area was selected from these centers using additional checks based on aerial photographs (Google Earth).

\section{A2.2.2 Results}

Figure A.2.1 shows the potential study area without no-go areas for UAVs in Oostelijk Flevoland (referred to as 'map $C^{\prime}$ in the previous subsection). In the green area in Figure A.2.1 areas of spatial variation were designated using the map of combinations of soil types, water table classes and landuse categories (Figure A.2.2) and the resulting map of normalized Shannon entropies indicating heterogeneity (Figure A.2.3). 


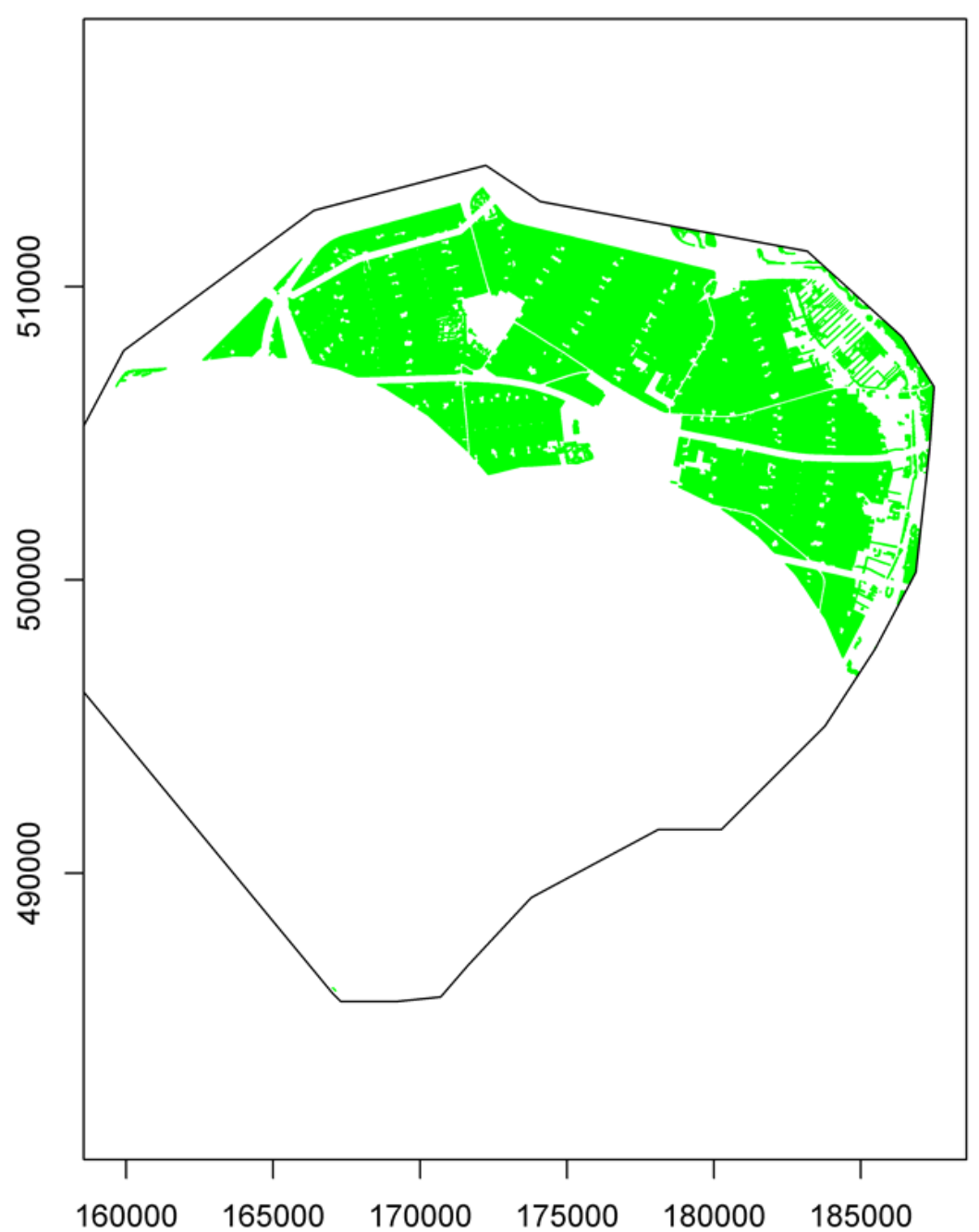

Figure A.2.1: Potential study area without no-go areas for UAVs in Oostelijk Flevoland

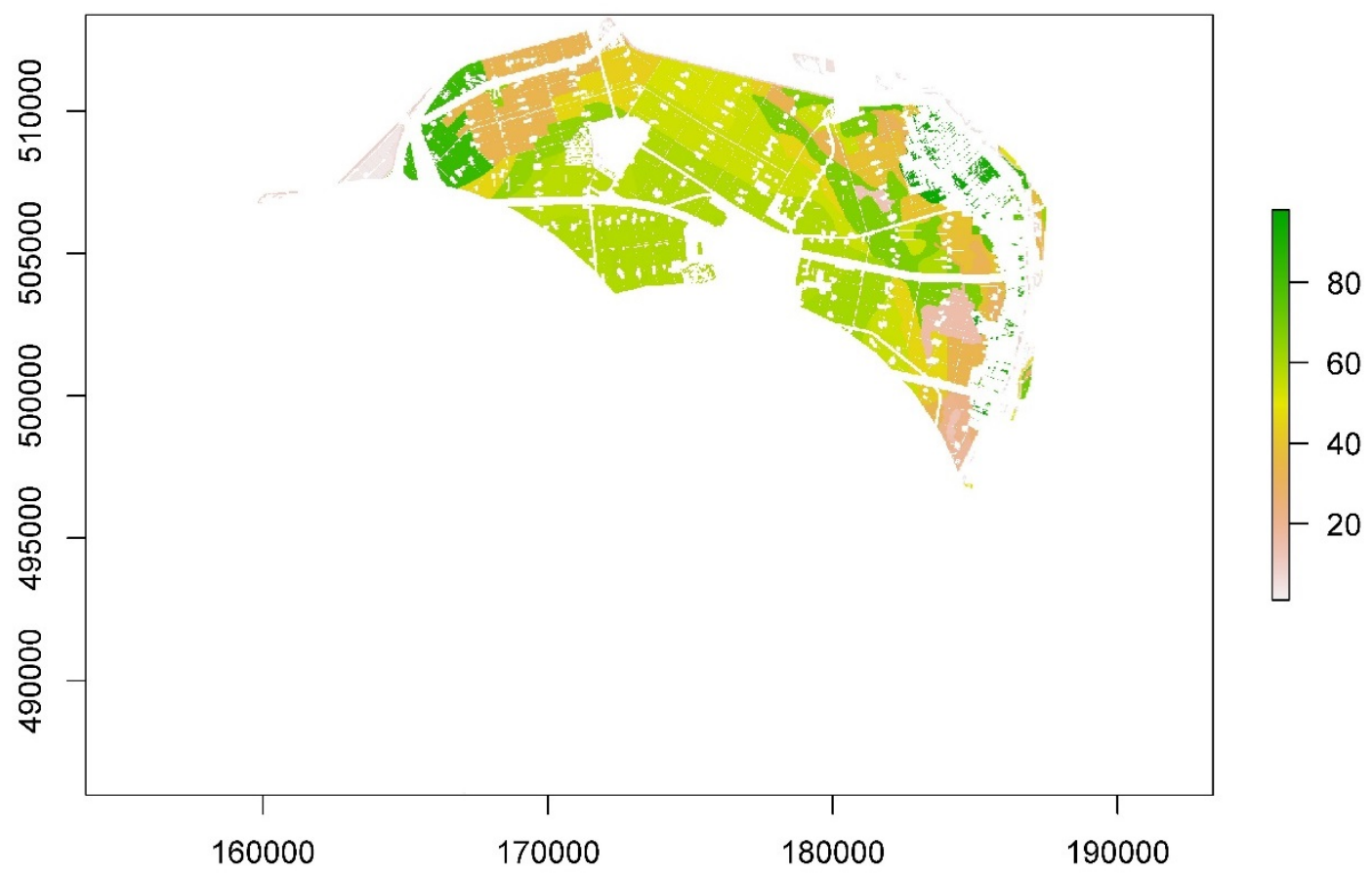

Figure A.2.2: Map of combinations of soil types, water table classes and land-use categories 


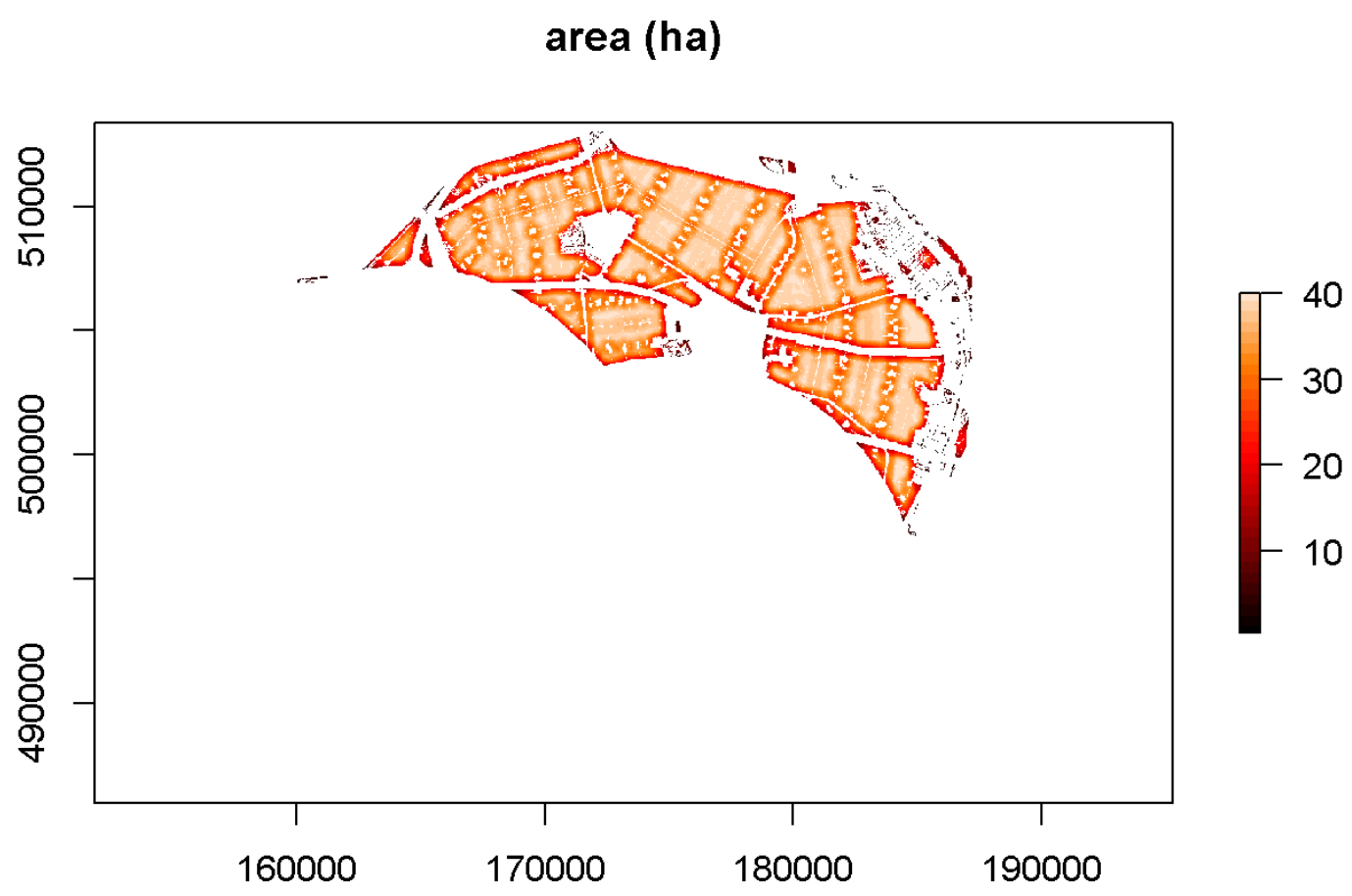

Figure A. 2.3: Map of normalized Shannon entropies, calculated from Figure A.2 using a search radius of about 357 meter around each pixel.

Figure A.2.4 shows the area of patches in a search radius of $357 \mathrm{~m}$ around each pixel, with a theoretical maximum of 40 hectares, indicating contiguity of patches.

\section{$\mathrm{H}_{\mathrm{n}}$}

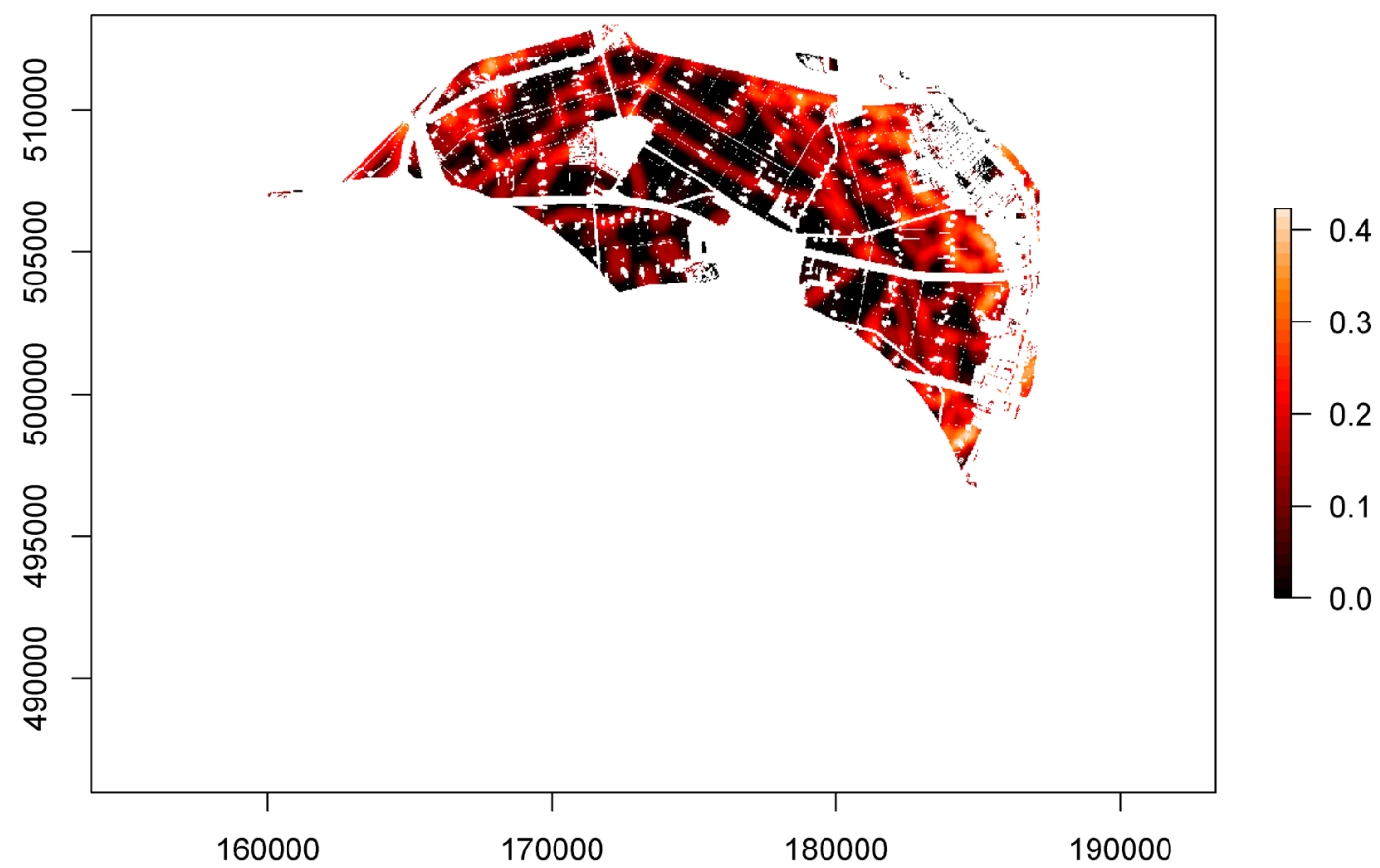

Figure A.2.4: Area of patches in a search radius of $357 \mathrm{~m}$ around each pixel.

Figure A.2.5 shows all locations with a normalized entropy greater than 0.35 and a contiguous area greater than 35 hat (centres of clustered pixels, calculated by the k-means algorithm). 


\section{$H_{n}$ soil-gwc-lu}

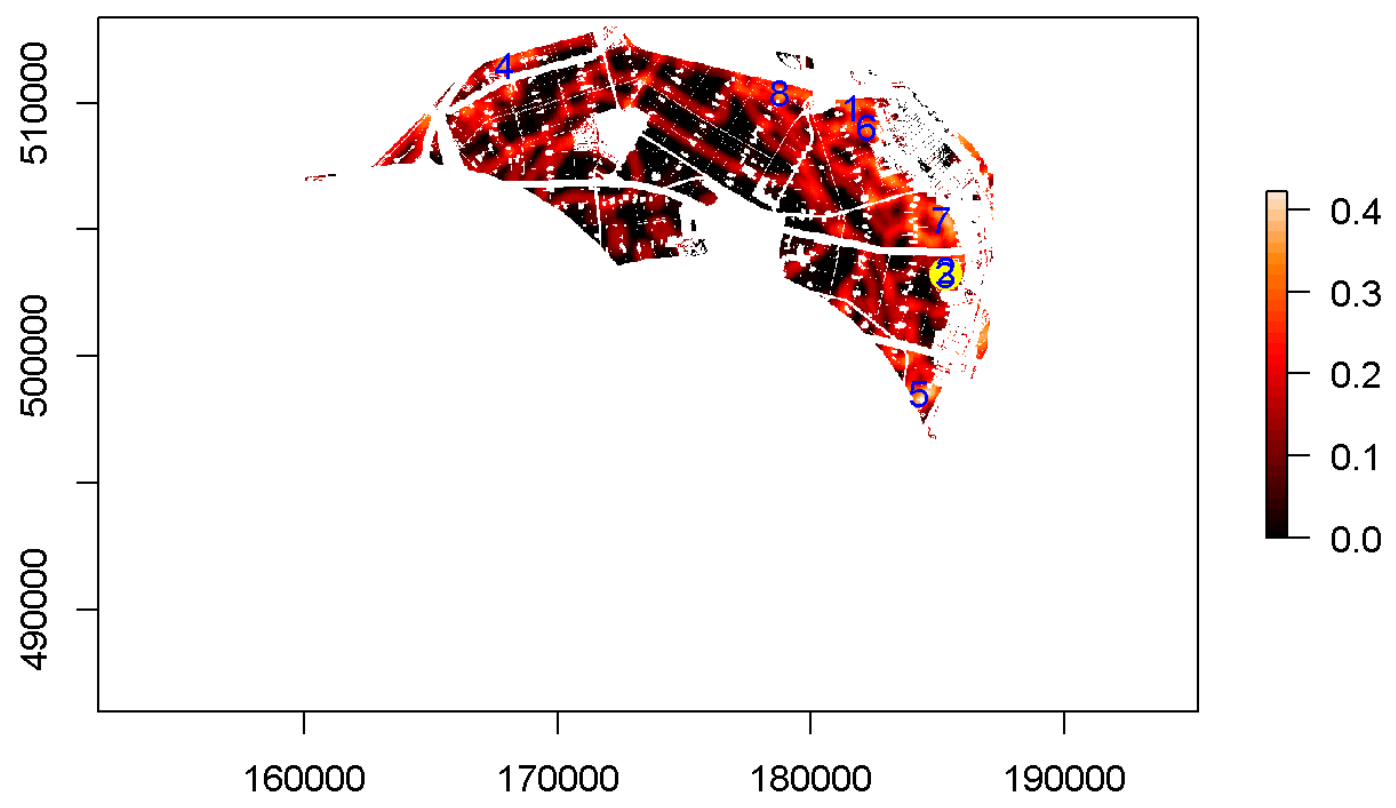

Figure A.2.5: Locations of areas with a normalized entropy greater than 0.35 and a contiguous area greater than 35 ha. The locations were calculated from clusters of pixels using the k-means algorithm. Location 3 (yellow) has been selected.

After additional checks on the basis of aerial photographs (Google Earth) location 3 in Figure A.2.5 was selected. Figure A.2.6 shows this location in close-up. After receiving permission from the land owners a study area of 40 hectares around the selected location was selected as study area for the validation experiment.

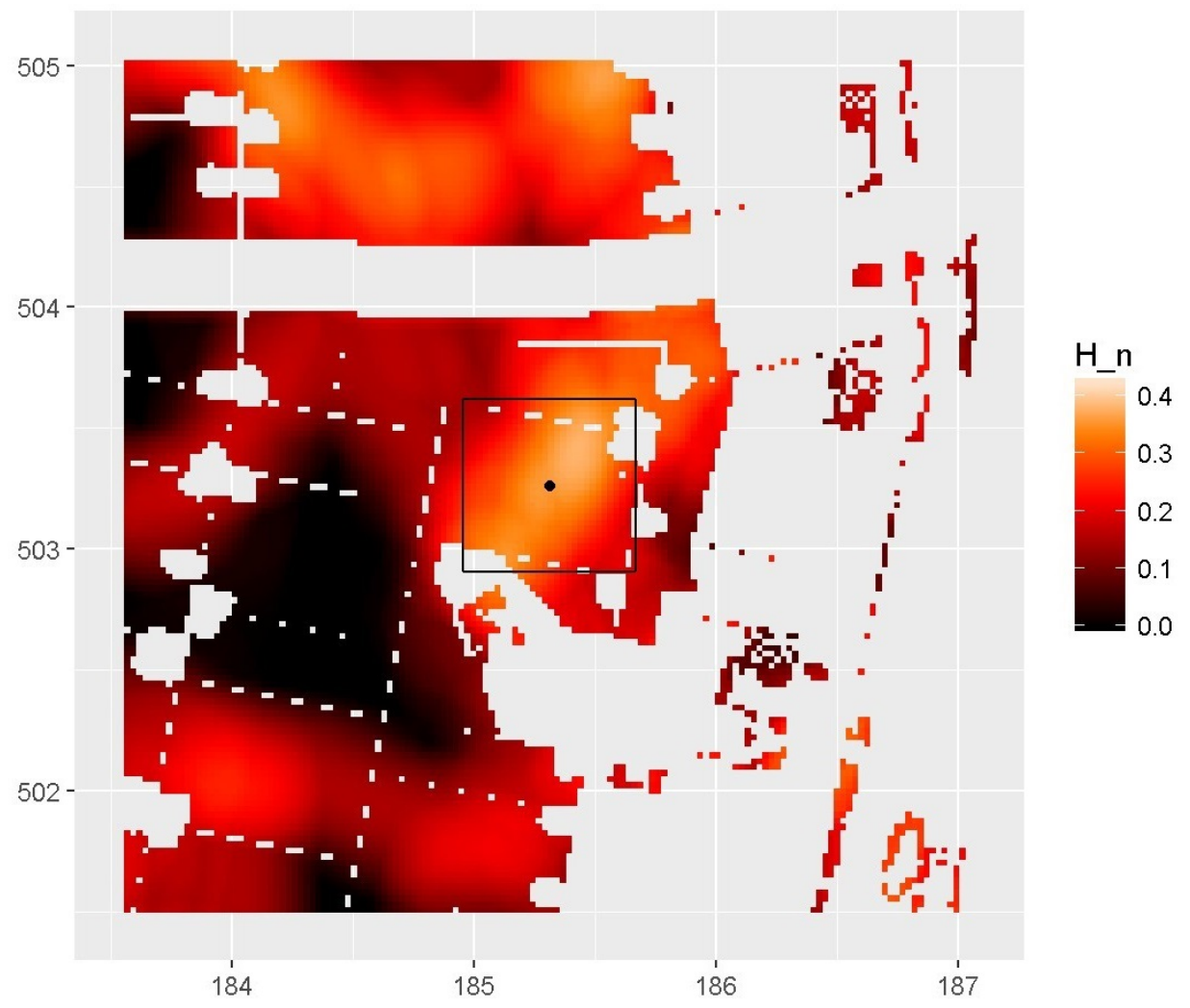

Figure A.2.6: Close-up of the selected location 3 in Figure A.2.5 



\section{Annex 3 Validation sampling strategy}

A3.1

Method

A distribution of sampling units for validation in both the geographic and the feature space was aimed for. To further the distribution of the sampling units in feature space a first stratification of the study area was made on the basis of the soil map. This resulted in seven strata. To further the distribution of the sampling units in the geographic space these seven strata were next subdivided in compact geographic strata using the R-package Spcosa. Within each of these geographic strata two sampling locations were selected by simple random sampling.

For calibration sampling the same methodology was followed using the nuclide concentrations measured by the gamma-ray spectrometer (ground measurement) as feature space.

\section{A3.2}

\section{Results}

Table A.3.1 summarizes the stratification of the study area. Figure A.3.1 shows the distribution of sampling units and strata in the study area for the validation samples.

Table A.3.1: Division of the study area into strata for validation samples

\begin{tabular}{cccc} 
Soil stratum & Soil type, Water table class & Geographic stratum & Areal size (ha) \\
\hline 1 & kVz, VI & 1 & 2.3416 \\
1 & kVz, VI & 2 & 2.4470 \\
\hline 2 & Mn12AF, V & 1 & 3.4207 \\
2 & Mn12AF, V & 2 & 2.3275 \\
2 & Mn12AF, V & 3 & 3.4309 \\
2 & Mn12AF, V & 4 & 2.3720 \\
\hline 3 & Mn15ApF, V & 1 & 2.2289 \\
3 & Mn15ApF, V & 2 & 2.9090 \\
3 & Mn15ApF, V & 3 & 2.0997 \\
\hline 4 & Mn15AF, V & 1 & 2.7192 \\
4 & Mn15AF, V & 2 & 2.5233 \\
4 & Mn15AF, V & 3 & 2.2654 \\
4 & $M n 15 A F, V$ & 4 & 3.3591 \\
\hline 5 & Zn50A, VI & 1 & 0.2181 \\
\hline 6 & Mv51Ap/Mn25Awp, VI & 1 & 1.8565 \\
6 & Mv51Ap/Mn25Awp, VI & 2 & 2.6758 \\
6 & Mv51Ap/Mn25Awp, VI & 3 & 3.1003 \\
6 & Mv51Ap/Mn25Awp, VI & 4 & 2.9758 \\
6 & Mv51Ap/Mn25Awp, VI & 5 & 2.4753 \\
6 & Mv51Ap/Mn25Awp, VI & 6 & 2.9227 \\
\hline 7 & Mn15ApF, VI & 1 & 2.8279 \\
7 & Mn15ApF, VI & 4.0484 \\
\hline
\end{tabular}

kVz: peat soil with a clayey top layer and a sandy subsoil.

Mn12AF: Marine, calcareous sandy loam $(8-17.5 \%<2 \mu \mathrm{m})$ with a sandy subsoil starting between 40 and $80 \mathrm{~cm}$, reworked.

Mn15ApF: Marine, calcareous sandy loam $(8-17.5 \%<2 \mu \mathrm{m})$ with a Pleistocene sandy subsoil starting between 80 and $120 \mathrm{~cm}$, reworked. 
Mn15AF: Marine, calcareous sandy loam $(8-17.5 \%<2 \mu \mathrm{m})$, reworked.

Zn50A: Medium fine sand (M50 150-210 $\mu \mathrm{m}$ ), calcareous.

Mv51Ap: Calcareous sandy (clay) loam $(8-25 \%<2 \mu \mathrm{m})$ with a peaty layer of at least $40 \mathrm{~cm}$ thickness starting between 40 and $80 \mathrm{~cm}$, and a Pleistocene sandy subsoil starting between 80 and $120 \mathrm{~cm}$. Mn25Awp: Calcareous sandy clay loam $(17.5-25 \%<2 \mu \mathrm{m})$ with a peaty layer of $15-40 \mathrm{~cm}$ thickness starting between 40 and $80 \mathrm{~cm}$, and a Pleistocene sandy subsoil starting between 80 and $120 \mathrm{~cm}$. Water table class $V$ : top of seasonal fluctuation $0-40 \mathrm{~cm}$ below ground surface, bottom of seasonal fluctuation $>120 \mathrm{~cm}$ below ground surface.

Water table class VI: top of seasonal fluctuation $40-80 \mathrm{~cm}$ below ground surface, bottom of seasonal fluctuation $>120 \mathrm{~cm}$ below ground surface

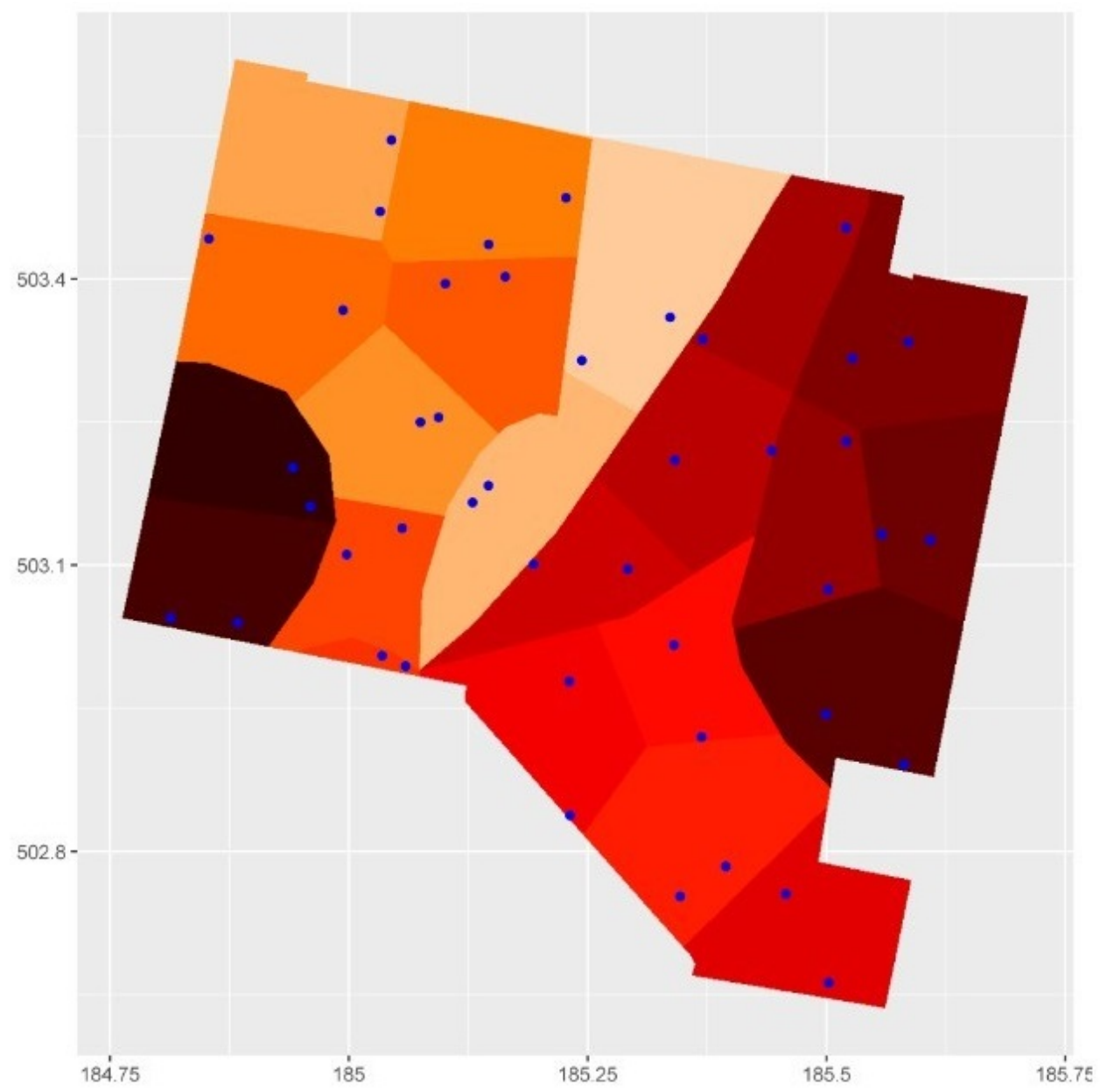

Figure A.3.1: Locations of the validation points 


\section{Verschenen documenten in de reeks Technical reports van de Wettelijke Onderzoekstaken Natuur}

\& Milieu vanaf 2017

WOt-technical reports zijn verkrijgbaar bij het secretariaat van Unit Wettelijke Onderzoekstaken Natuur \& Milieu te Wageningen. T 0317 - 4854 71; E info.wnm@wur.nl

WOt-technical reports zijn ook te downloaden via de website www.wur.nl/wotnatuurenmilieu

88 Mol-Dijkstra, J.P.\& G.J Reinds (2017). Technical documentation of the soil model VSD+; Status $A$

89 Arets, E.J.M.M., J.W.H van der Kolk, G.M. Hengeveld, J.P. Lesschen, H. Kramer, P.J. Kuikman \& M.J. Schelhaas (2017). Greenhouse gas reporting for the LULUCF sector in the Netherlands. Methodological background, update 2016

90 Bruggen, C. van, A. Bannink, C.M. Groenestein, J.F.M. Huijsmans, H.H. Luesink, S.V. Oude Voshaar, S.M. van der Sluis, G.L. Velthof \& J. Vonk (2017). Emissies naar lucht uit de landbouw in 2014. Berekeningen met het model NEMA

91 Os van, J., M.G.T.M. Bartholomeus, L.J.J. Jeurissen \& C.G. van Reenen (2017). Rekenregels rundvee voor de landbouwtelling. Verantwoording van het gebruik van I\&R gegevens voor de landbouwtelling

Haas, W. de, R.J. Fontein \& M. Pleijte (2017). Is eenvoudig beter? Twee essays natuur en landschap in het nieuwe omgevingsbeleid

Schuiling, C., A.M. Schmidt, I.J. La Rivière \& R.A. Smidt (2017). Beschermde gebiedenregister; Technische documentatie, Status A.

Henkens, R.J.H.G., M.M.P. van Oorschot en J. Ganzevles (2017). Bijdrage van Green Deals aan de beleidsdoelen voor natuur en biodiversiteit

Arets, E.J.M.M., J.W.H van der Kolk, G.M. Hengeveld, J.P. Lesschen, H. Kramer, P.J. Kuikman \& M.J. Schelhaas (2017). Greenhouse gas reporting for the LULUCF sector in the Netherlands. Methodological background, update 2017

IJsseldijk, L.L., M.J.L. Kik, L. Solé \& A. Gröne (2017). Postmortaal onderzoek van bruinvissen (Phocoena phocoena) uit Nederlandse wateren, 2016.

97 Verburg, R.W., W.H.G.J. Hennen, L.F. Puister, R. Michels \& K. van Duijvendijk (2017). Estimating costs of nature management in the European Union; Exploration modelling for PBL's Nature Outlook

Bruggen, C. van, A. Bannink, C.M. Groenestein, J.F.M. Huijsmans, H.H. Luesink, S.V. Oude Voshaar, S.M. van der Sluis, G.L. Velthof \& J. Vonk (2017). Emissies naar lucht uit de landbouw in 2015. Berekeningen met het model NEMA

99 Kuiters, A.T., G.A. de Groot, D.R. Lammertsma, H.A.H. Jansman \& J. Bovenschen (2017). Genetische monitoring van de Nederlandse otterpopulatie; Ontwikkeling van populatieomvang en genetische status 2016/2017
100 Adriaanse, P.I. \& W.H.J Beltman (2017) Comparison of pesticide concentrations at drinking water abstraction points in The Netherlands simulated by DROPLET version 1.2 and 1.3.2 model suites

101 Daamen, W.P., A.P.P.M. Clerkx \& M.J. Schelhaas (2017). Veldinstructie Zevende Nederlandse Bosinventarisatie (2017-2021)

102 Boer, T.A. de \& F.L. Langers (2017). Maatschappelijk draagvlak voor natuurbeleid en betrokkenheid bij natuur in 2017

103 Buijs, A.E., B.H.M. Elands \& C.S.A. van Koppen (2017) Vijfentwintig jaar burgerbetrokkenheid in het natuurbeleid. Analyse van beleidsdiscoursen en publiek draagvlak

104 Cremer, J.S.M., S.M.J.M. Brasseur., A. Meijboom, J. Schop \& J.P. Verdaat (2017). Monitoring van gewone en grijze zeehonden in de Nederlandse Waddenzee, 2002-2017

105 Glorius, S.T., A. Meijboom, J.T. van der Wal \& J.S.M. Cremer (2017). Ontwikkeling van enkele mosselbanken in de Nederlandse Waddenzee, situatie 2016

106 Hennekens, S.M., W.A. Ozinga \& J.H.J. Schaminée (2017). BioScore 3 - Plants. Background and preprocessing of distribution data

107 Melman, Th.C.P., M.H.C. van Adrichem, M. Broekmeyer, J. Clement, R. Jochem, H.A.M. Meeuwsen, F.G.W.A. Ottburg, A.G.M. Schotman \& T. Visser (2017). Natuurcombinaties en Europese natuurdoelen; Ontwikkeling van een methode om natuurdoelen te realiseren buiten het Natuurnetwerk Nederland

108 Vries, S. de, W. Nieuwenhuizen \& J.M.J. Farjon (2017) HappyHier: hoe gelukkig is men waar?; Gegevensverzameling en bepaling van de invloed van het type grondgebruik - deel I.

109 Overbeek, M.M.M., E. Smeets \& D. Verhoog (2017). Biobased materialen, circulaire economie en natuurlijk kapitaal.

110 Pouwels, R., G.W.W. Wamelink, M.H.C. van Adrichem, R. Jochem, R.M.A. Wegman en B. de Knegt. (2017). MetaNatuurplanner v4.0 - Status A; Toepassing voor Evaluatie Natuurpact

111 Commissie Deskundigen Meststoffenwet (2017). Advies Mestverwerkingspercentages 2018.

112 Koffijberg K., J.S.M. Cremer, P. de Boer, J. Nienhuis, H. Schekkerman, J. Postma \& K. Oosterbeek (2017). Broedsucces van kustbroedvogels in de Waddenzee. Resultaten 2015-2016 en trends in broedsucces in 2005-2016. 
113 Arets, E.J.M.M., J.W.H van der Kolk, G.M. Hengeveld, J.P. Lesschen, H. Kramer, P.J. Kuikman \& M.J. Schelhaas (2018). Greenhouse gas reporting for the LULUCF sector in the Netherlands. Methodological background, update 2018

114 Bos-Groenendijk, G.I. en C.A.M. van Swaay (2018). Standaard Data Formulieren Natura 2000gebieden; Aanvullingen vanwege wijzigingen in Natura 2000-aanwijzingsbes/uiten

115 Vonk, J. , S.M. van der Sluis, A. Bannink, C. van Bruggen, C.M. Groenestein, J.F.M. Huijsmans, J.W.H. van der Kolk, L.A. Lagerwerf, H.H. Luesink, S.V. Oude Voshaar \& G.L. Velthof (2018.) Methodology for estimating emissions from agriculture in the Netherlands - update 2018. Calculations of $\mathrm{CH} 4, \mathrm{NH} 3, \mathrm{N2O}$, NOx, PM10, PM2.5 and $\mathrm{CO} 2$ with the National Emission Model for Agriculture (NEMA)

116 IJsseldijk, L.L., M.J.L. Kik, \& A. Gröne (2018). Postmortaal onderzoek van bruinvissen (Phocoena phocoena) uit Nederlandse wateren, 2017. Biologische gegevens, gezondheidsstatus en doodsoorzaken.

117 Mattijssen, T.J.M. \& I.J. Terluin (2018). Ecologische citizen science; een weg naar grotere maatschappelijke betrokkenheid bij de natuur?

118 Aalbers, C.B.E.M., D. A. Kamphorst \& F. Langers (2018). Bedrijfs- en burgerinitiatieven in stedelijke natuur. Hun succesfactoren en knelpunten en hoe de lokale overheid ze kan helpen slagen.

119 Bruggen, C. van, A. Bannink, C.M. Groenestein, J.F.M. Huijsmans, L.A. Lagerwerf, H.H. Luesink, S.M. van der Sluis, G.L. Velthof \& J. Vonk (2018). Emissies naar lucht uit de landbouw in 2016. Berekeningen met het model NEMA

120 Sanders, M.E., F. Langers, R.J.H.G. Henkens, J.L.M. Donders, R.I. van Dam, T.J.M. Mattijssen \& A.E. Buijs (2018). Maatschappelijke initiatieven voor natuur en biodiversiteit; Een schets van de reikwijdte en ecologische effecten en potenties van maatschappelijke initiatieven voor natuur in feiten en cijfers

121 Farjon, J.M.J., A.L. Gerritsen, J.L.M. Donders, F. Langers \& W. Nieuwenhuizen (2018). Condities voor natuurinclusief handelen. Analyse van vier praktijken van natuurinclusief ondernemen

122 Gerritsen, A.L., D.A. Kamphorst \& W. Nieuwenhuizen (2018). Instrumenten voor maatschappelijke betrokkenheid. Overzicht en analyse van vier cases

123 Vullings, L.A.E., A.E. Buijs, J.L.M. Donders, D.A. Kamphorst, H. Kramer \& S. de Vries (2018). Monitoring van groene burgerinitiatieven; Analyse van de resultaten van een pilot en nulmeting in vier gemeenten

124 Boonstra, F.G., Th.C.P. Melman, W. Nieuwenhuizen \& A. Gerritsen (2018). Aanpak evaluatie stelselvernieuwing agrarisch natuurbeheer;
Uitgangspunten en opties voor een beleidsevaluatie

125 Vullings, L.A.E., A.E. Buijs, J.L.M. Donders \& D.A. Kamphorst (2018). Monitoring van groene burgerinitiatieven; Methodiek, indicatoren en ervaring met pilot en nulmeting.

126 Beltman, W.H.J., M.M.S. ter Horst, P.I. Adriaanse \& A. de Jong (2018). Manual for FOCUS_TOXSWA v5.5.3 and for expert use of TOXSWA kernel v3.3; User's Guide version 5

127 Van der Heide, C.M. \& M.M.M. Overbeek (2018). Natuurinclusief handelen en ondernemen. Scopingstudie 'Bedrijven, economie en natuur'

128 Langers, F. (2018). Recreatie in groenblauwe gebieden; Actualisatie van CLO-indicator 1258 (Bezoek aan groenblauwe gebieden) op basis van data van het Continu Vrijetijdsonderzoek uit 2015

129 Glorius, S.T., I.Y.M. Tulp, A. Meijboom, L.J. Bolle and C. Chen (2018). Developments in benthos and fish in gullies in an area closed for human use in the Wadden Sea; 2002-2016

130 Kamphorst, D.A \& T.J.M. Mattijssen (2018). Scopingstudie Vermaatschappelijking van natuur. Een overzicht van onderzoek bij Wageningen Universiteit \& Research voor het Planbureau voor de Leefomgeving en het ministerie van Landbouw, Natuur en Voedselkwaliteit

131 Breman, B.C., T.J.M. Mattijssen \& T.M. Stevens (2018). Natuur 2.0. Het natuurdebat op social media.

132 Vries, S. de \& W. Nieuwenhuizen (2018) HappyHier: hoe gelukkig is men waar?; Gegevensverzameling en bepaling van de invloed van het type grondgebruik, deel II

133 Kistenkas, F.H., W. Nieuwenhuizen, D.A. Kamphorst \& M.E.A. Broekmeyer (2018). Natuur-en landschap in de Omgevingswet.

135 Sanders, M.E. (2018). Voortgang realisatie natuurnetwerk. Technische achtergronden bij de digitale Balans van de Leefomgeving 2018

137 Egmond, F.M. van, S. van der Veeke, M. Knotters R.L. Koomans, D. Walvoort, J. Limburg (2018). Mapping soil texture with a gamma-ray spectrometer: comparison between UAV and proximal measurements and traditional sampling; Validation study 



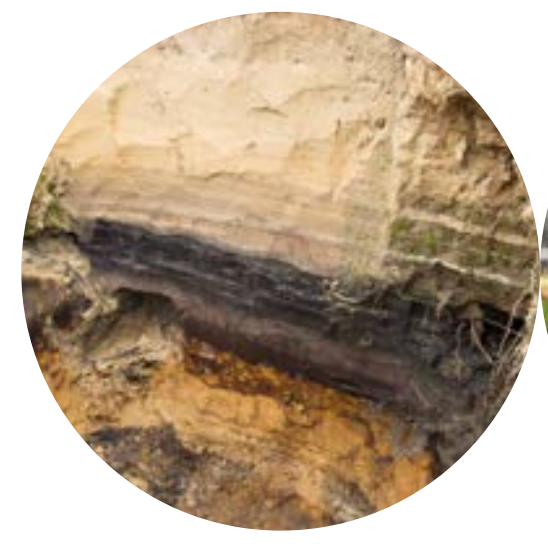

Theme Register of the Subsurface Wettelijke Onderzoekstaken Natuur \& Milieu

P.O. Box 47

6700 AA Wageningen

T (0317) 485471

E info.wnm@wur.nl

ISSN $2352-2739$

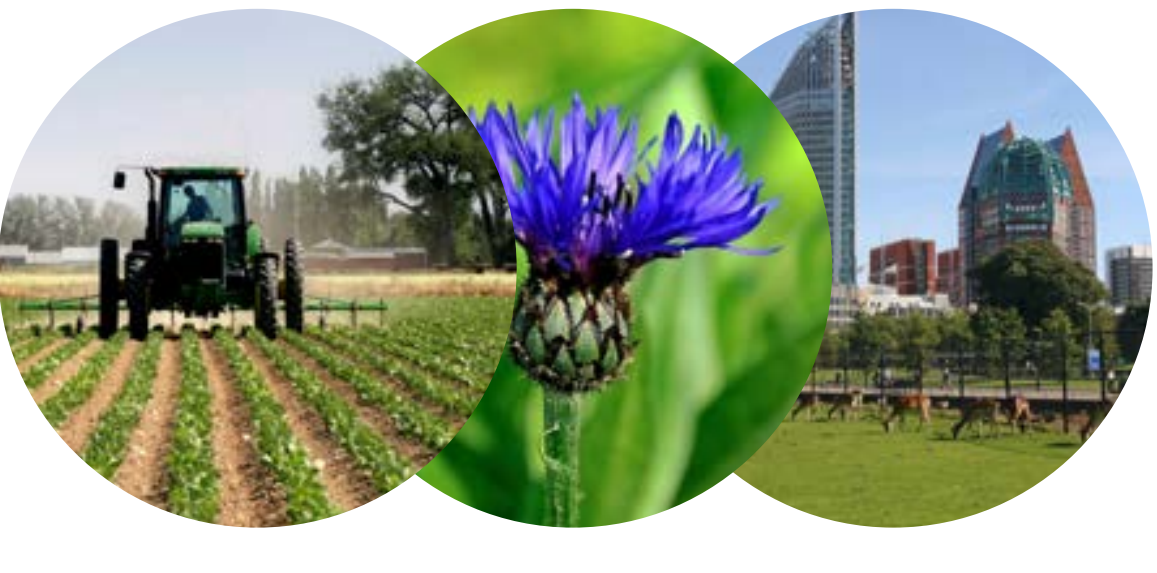

The mission of Wageningen University \& Research is "To explore the potential of nature to improve the quality of life". Under the banner Wageningen University \& Research, Wageningen University and the specialised research institutes of the Wageningen Research Foundation have joined forces in contributing to finding solutions to important questions in the domain of healthy food and living environment. With its roughly 30 branches, 5,000 employees and 10,000 students, Wageningen University \& Research is one of the leading organisations in its domain. The unique Wageningen approach lies in its integrated approach to issues and the collaboration between different disciplines. 